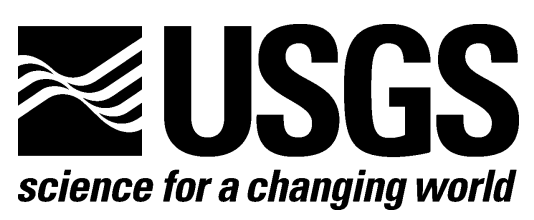

Prepared in cooperation with the Washington State Department of Ecology

\title{
Beach Morphology Monitoring in the Elwha River Littoral Cell, 2004-2009
}

By Jonathan A. Warrick, Douglas A. George, Andrew W. Stevens, Jodi Eshleman, Guy Gelfenbaum, George M. Kaminsky, Andrew K. Schwartz, and Matt Beirne

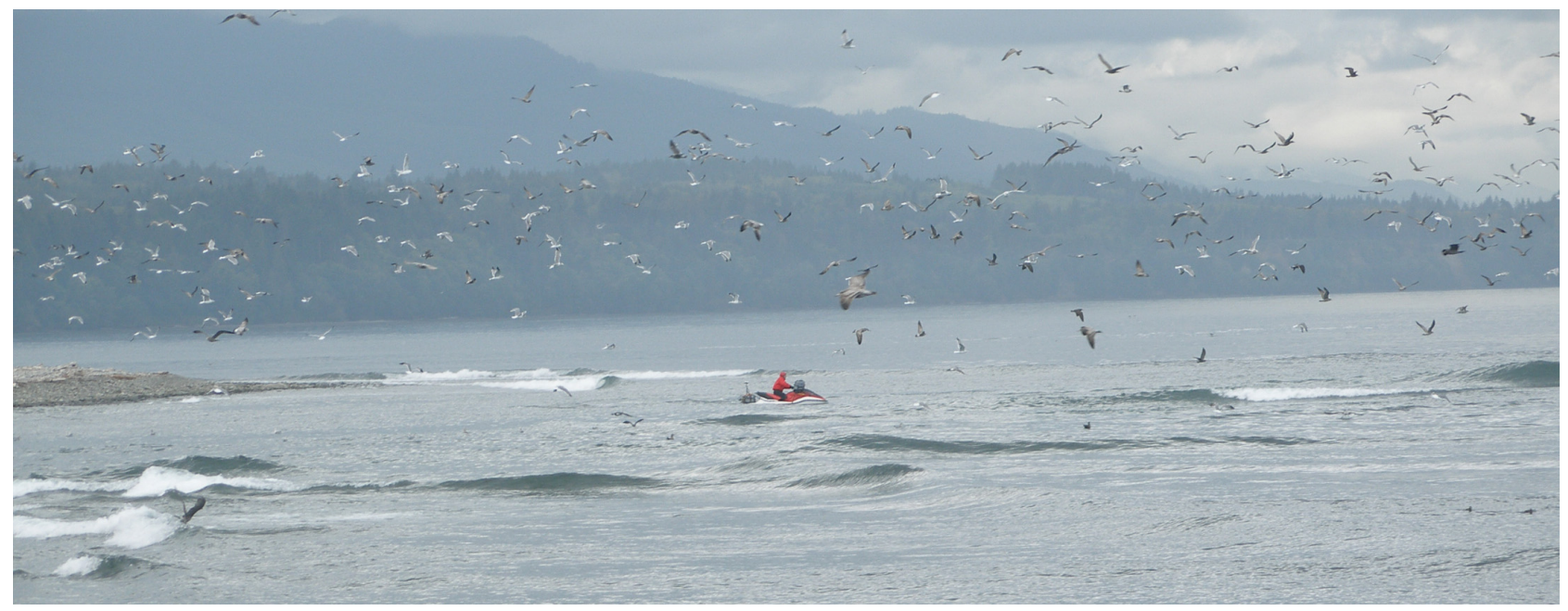

Data Series 288, version 1.1

U.S. Department of the Interior

U.S. Geological Survey 


\title{
U.S. Department of the Interior \\ KEN SALAZAR, Secretary
}

\section{U.S. Geological Survey \\ Marcia K. McNutt, Director}

\author{
U.S. Geological Survey, Reston, Virginia 2007 \\ Revised and reprinted: 2010
}

For product and ordering information:

World Wide Web: http://www.usgs.gov/pubprod

Telephone: 1-888-ASK-USGS

For more information on the USGS - the Federal source for science about the Earth, its natural and living resources, natural hazards, and the environment:

World Wide Web: http://www.usgs.gov

Telephone: 1-888-ASK-USGS

Suggested citation:

Warrick, Jonathon A., George, Douglas A., Stevens, Andrew W., Eshleman, Jodi, Gelfenbaum, Guy, Kaminsky, George. M., Schwartz, Andrew K., and Bierne, Matt, 2007, revised 2010, Beach morphology monitoring in the Elwha River littoral cell, 2004-2009: U. S. Geological Survey, Data Series 288, v.1.1, 59 p. and data folder [http://pubs.usgs.gov/ds/288/].

Any use of trade, product, or firm names is for descriptive purposes only and does not imply endorsement by the U.S. Government.

Although this report is in the public domain, permission must be secured from the individual copyright owners to reproduce any copyrighted material contained within this report. 


\section{Contents}

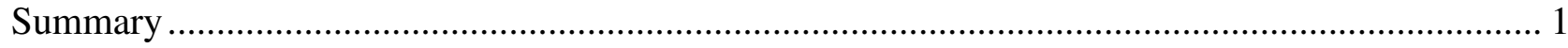

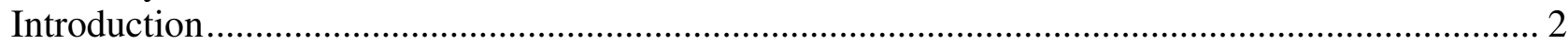

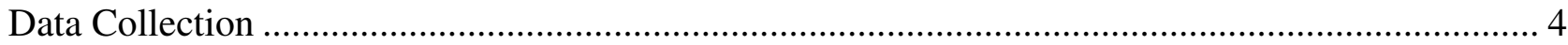

Nearshore Bathymetry/Topography Data.......................................................................... 4

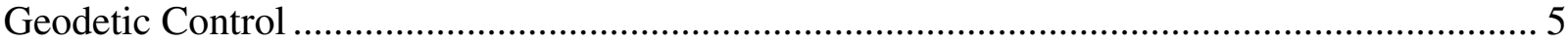

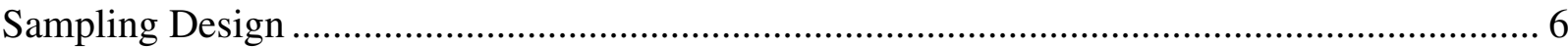

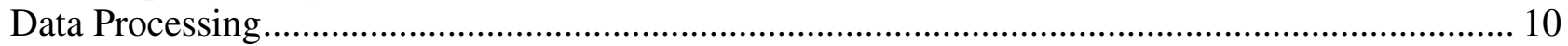

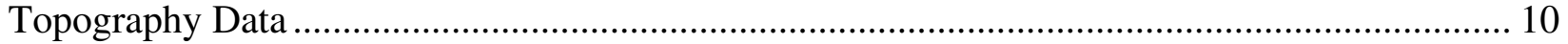

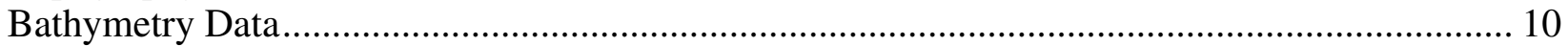

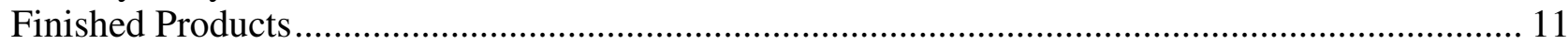

Bathymetric/Topographic Profile Data Files..................................................................... 11

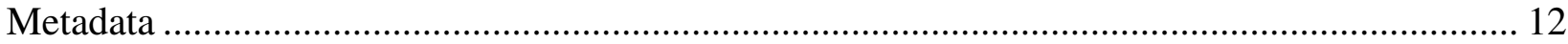

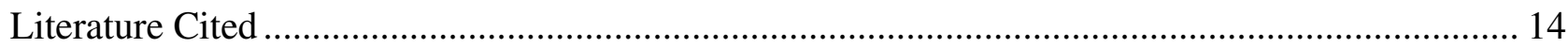

Appendix A - September 2004 Field Collection....................................................................... 16

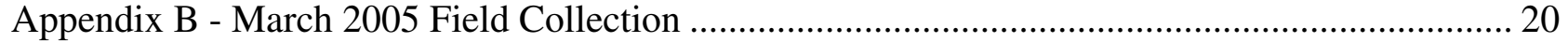

Appendix C - August-September 2005 Field Collection ......................................................... 24

Appendix D - January 2006 Field Collection ........................................................................ 28

Appendix E - April 2006 Field Collection................................................................................ 31

Appendix F - September 2006 Field Collection ..................................................................... 35

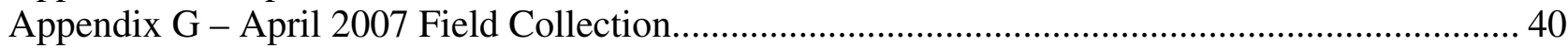

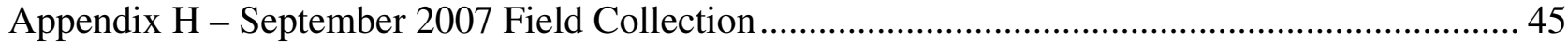

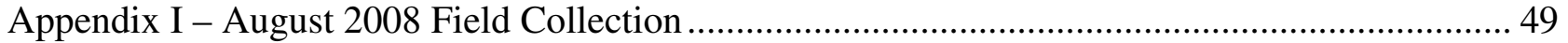

Appendix J - September 2009 Field Collection ......................................................................... 54 


\section{Figures}

Figure 1. Study area on the Olympic Peninsula, northwest Washington.

Figure $2 \underline{A}$. Elwha profile lines shown in red for the entire study area. Inset regions for figures $2 \underline{B}-\underline{E}$ are shown with blue boxes and labeled by A-D. Axes are Washington State Plane North (km). 6

Figure $\mathbf{2} \underline{\boldsymbol{B}}$. Elwha profile lines for the Freshwater Bay portion of the study area. Every tenth line is labeled with the corresponding line number. Axes are Washington State Plane North (km)..... 7

Figure 2 $\underline{\boldsymbol{C}}$. Elwha profile lines for the delta-region portion of the study area. Every tenth line is labeled with the corresponding line number. Axes are Washington State Plane North $(\mathrm{km}) \ldots . . .8$

Figure 2D. Elwha profile lines for the east delta portion of the study area. Every tenth line is labeled with the corresponding line number. Axes are Washington State Plane North $(\mathrm{km})$............... 9

Figure 2E. Elwha Planned Lines for the Ediz Hook portion of the study area. Every tenth line is labeled with the corresponding line number. Axes are Washington State Plane North $(\mathrm{km}) \ldots . . .9$

Figure 3. Overlap and alignment of bathymetric and topographic Line 151, September 2006. ...... 13

Figure A1. Elwha September 2004 surveyed lines. ................................................................ 16

Figure A2. Elwha September 2004 surveyed lines (delta region). ........................................... 17

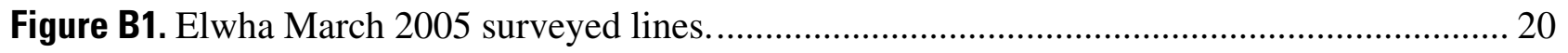

Figure B2. Elwha March 2005 surveyed lines (delta region)................................................... 21

Figure C1. Elwha August-September 2005 surveyed lines......................................................... 24

Figure C2. Elwha August-September 2005 surveyed lines (delta region). ................................ 25

Figure D1. Elwha January 2006 surveyed lines. Only topography data were collected................... 28

Figure D2. Elwha January 2006 surveyed lines (delta region). Only topography data were collected.

Figure E2. Elwha April 2006 surveyed lines (delta region)..................................................... 32

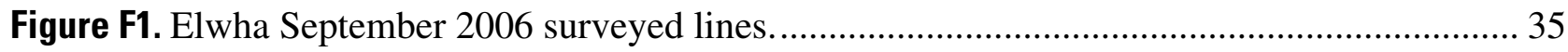

Figure F2. Elwha September 2006 surveyed lines (delta region). .............................................. 36

Figure G1. Elwha April 2007 surveyed lines. Only topography data were collected..................... 40

Figure G2. Elwha April 2007 surveyed lines (delta region). Only topography data were collected. 41

Figure H1. Elwha September 2007 surveyed lines. ............................................................... 45

Figure H2. Elwha September 2007 surveyed lines (delta region). ............................................. 46

Figure I1. Elwha August 2008 surveyed lines. ...................................................................... 49

Figure 12. Elwha August 2008 surveyed lines (delta region). .................................................. 50

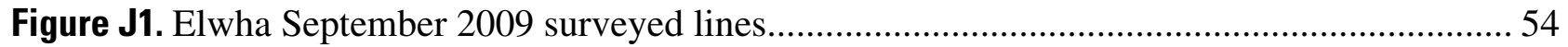

Figure J2. Elwha September 2009 surveyed lines (delta region).......................................... 55 


\section{Tables}

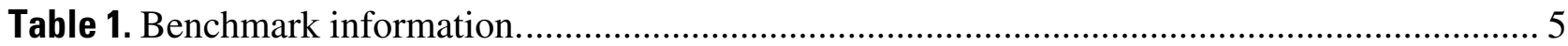

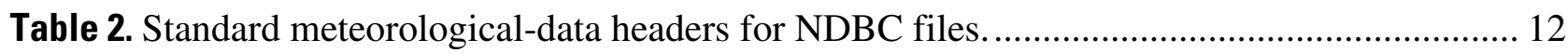

Table A. Bathymetric and topographic lines for the September 2004 survey................................... 17

Table B. Bathymetric and topographic lines for the March 2005 survey. ............................................ 21

Table C. Bathymetric and topographic lines for the August-September 2005 survey. .................... 25

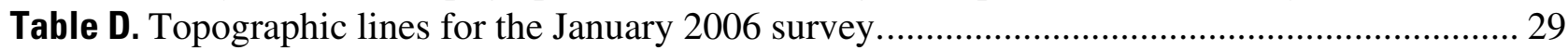

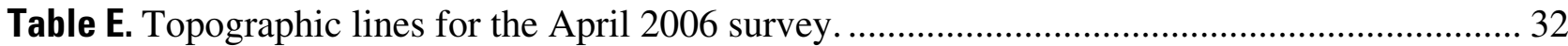

Table F. Bathymetric and topographic lines for the September 2006 survey.................................... 36

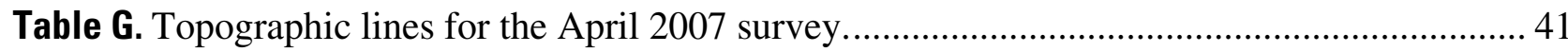

Table H. Bathymetric and topographic lines for the September 2007 survey................................... 46

Table I. Bathymetric and topographic lines for the August 2008 survey......................................... 50

Table J. Bathymetric and topographic lines for the September 2009 survey................................... 55 


\section{Beach Morphology Monitoring in the Elwha River Littoral Cell, 2004-2009}

By Jonathan A. Warrick', Douglas A. George', Andrew W. Stevens', Jodi Eshleman', Guy Gelfenbaum', George M. Kaminsky ${ }^{2}$, Andrew K. Schwartz ${ }^{2}$ and Matt Beirne ${ }^{3}$

\section{Summary}

This report describes the methods used, data collected, and results of the Beach Morphology Monitoring Program in the Elwha River Littoral Cell, starting in 2004. The U.S. Geological Survey and the Washington State Department of Ecology collaborated in the data collection with the support of the local Lower Elwha Klallam Tribe. Beach monitoring efforts consisted of collecting topographic and bathymetric horizontal and vertical position data by using a Real Time Kinematic Differential Global Positioning System (RTK-DGPS). The monitoring program was designed to characterize the littoral system of the Elwha River before the scheduled removal of two large dams in 2012. A primary objective of this work is to quantitatively describe the topography and bathymetry of the Elwha River littoral system so that the effects of dam removal may be quantified. Sediment inputs following dam removal are hypothesized to result in (A) larger amounts of fine sediment grain-sizes entering the littoral system and, (B) a reduction or reversal of coastal erosion.

1 - U.S. Geological Survey, Santa Cruz, Calif.

2 - Washington Department of Ecology, Olympia, Wash.

3 - Lower Elwha Klallam Tribe, Port Angeles, Wash. 


\section{Introduction}

The Elwha River of the Olympic Peninsula in Washington has two major dams, built in 1910 and 1926, that have significantly reduced sediment flux to the coast and removed most of the historic spawning habitats of native salmonids (Olympic National Park, 1996). Due to these environmental issues, the dams have been scheduled to be removed during a two-year process beginning in 2012 . Investigations suggest that 13 million cubic meters of sediment will be released by the dam removal, and that this material will be deposited in the fluvial and coastal systems downstream (Randle and others, 1996; Childers and others, 2000). Coastal sedimentation is expected to reduce, or perhaps reverse, the current trend of beach erosion in the local littoral cell.

The Coastal and Marine Geology Program (CMG) of the U.S. Geological Survey (USGS) has established a scientific program to characterize the littoral system of the Elwha River. A primary objective of this work is to quantitatively describe the topography and bathymetry of the Elwha River littoral system so that the effects of dam removal may be quantified. Sediment inputs following dam removal are hypothesized to result in (A) larger amounts of fine sediment grain-sizes entering the littoral system and, (B) a reduction or reversal of coastal erosion. To test the latter hypothesis, USGS CMG is collecting high-resolution topography and bathymetry data around the Elwha River delta in collaboration with the Washington Department of Ecology and the Lower Elwha Klallam Tribe (fig. 1). 


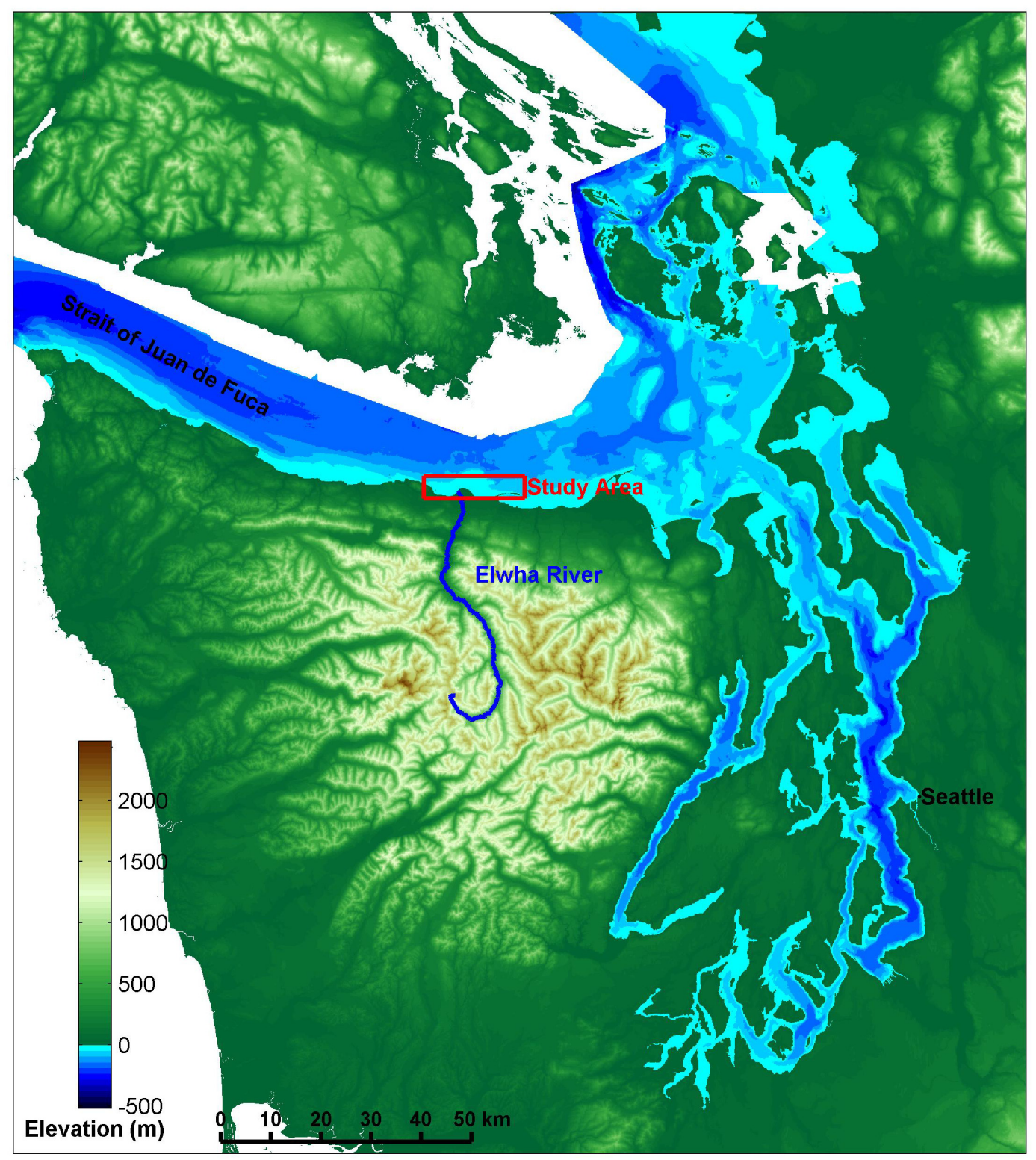

DEM Source: Finlayson and others (2000)

Figure 1. Study area on the Olympic Peninsula, northwest Washington. 
The purpose of this report is to describe and disseminate the topographic and bathymetric data collected in this program. As described in detail below, beach surveys are conducted twice per year during "summer" and "winter" profiles. High resolution bathymetric/topographic surveys are obtained with RTK-DGPS from both watercraft and hiked backpack systems. Following a presentation of the methods in the body of this report, a summary of each survey campaign and the resulting data are included in the Appendices. Each appendix describes an individual survey, and new editions of this report are issued following the completion of additional surveys and associated appendices.

\section{Data Collection}

The field data collection effort at the Elwha River mouth began in September 2004. The goal of data collection prior to the proposed dam removal was (1) to investigate topographic changes on seasonal, annual, and multi-annual periods of time for the region, and (2) to collect data that could be utilized to build and calibrate a numerical model to simulate hydrodynamics and sediment transport. Each field collection is described in an appendix attached to this data series.

\section{Nearshore Bathymetry/Topography Data}

The Coastal Profiling System (CPS), a hydrographic surveying system mounted on a Personal Watercraft (PWC), was used to collect bathymetric data along a 16-km stretch of coastline surrounding the mouth of the Elwha River. The CPS provides a fast and accurate method to obtain subaqueous bathymetric profiles by combining the high-accuracy positioning of a Differential Global Positioning System (DGPS), the efficiency of an acoustic echo sounder, and the mobility of a personal watercraft. The data were collected by using RTK-DGPS. Horizontal accuracy of approximately $\pm 3 \mathrm{~cm}$ and vertical accuracy of $\pm 5 \mathrm{~cm}$ are reported by the manufacturer of the survey equipment (Trimble Navigation Limited, 1998). Additional factors, such as multipath satellite obstructions, poor satellite geometry and 
poor atmospheric conditions, can combine to cause drifts in the vertical GPS by as much as $10 \mathrm{~cm}$ (Sallenger, and others 2003). Spatial variations in water temperature and salinity can affect depth estimates by as much as 3 percent of the water depth. Data were initially collected assuming a sound velocity of 1,500 m/s and corrected by using sound-velocity estimates during data processing as detailed below. Combined with the vertical uncertainty described above, a conservative estimate of the total vertical uncertainty for nearshore bathymetry measurements is approximately $15 \mathrm{~cm}$. A more complete discussion of the CPS technology and field techniques is found in MacMahan (2001) and Ruggiero and others (2005).

Topography data was obtained by using two backpack systems consisting of a GPS receiver and mounted antenna. The data also were collected in RTK-DGPS mode and stored in a handheld controller for downloading and data processing.

\section{Geodetic Control}

The Lower Elwha Klallam Tribe maintains a geodetic control network around the Elwha River delta. The coordinates of these benchmarks are included in table 1.

Table 1. Benchmark information.

\begin{tabular}{|c|c|c|c|}
\hline Benchmark & Northing $^{1}$ & Easting $^{1}$ & Elevation $^{\mathbf{2}}$ \\
\hline 1 & 131004.86 & 296580.06 & 4.01 \\
\hline 2 & 131207.93 & 296870.88 & 3.41 \\
\hline 3 & 131335.42 & 297184.43 & 3.34 \\
\hline 4 & 131452.67 & 297464.30 & 3.89 \\
\hline 5 & 131502.92 & 297727.64 & 3.44 \\
\hline 6 & 131279.86 & 298095.69 & 2.76 \\
\hline
\end{tabular}

${ }^{1}$ Wash. State Plane North NAD $83(\mathrm{~m})$.

${ }^{2}$ NAVD $88(\mathrm{~m})$. 


\section{Sampling Design}

A traditional sampling design for the CPS system consists of planned profile lines that are perpendicular to the shoreline and extend from a project-specific water depth to the beach. A line file was developed with line spacing that varied depending on the relative importance of a region to satisfy the project goals (figs. $2 \underline{A}-\underline{E}$ ). For example, survey lines were densest in the immediate vicinity of the river mouth as this area was determined to be the highest priority. The depth at the seaward endpoints of the lines varied but in most cases was deeper than $20 \mathrm{~m}$. The topography lines were extensions of the bathymetry lines from the upper portion of the beach berm to as low on the beach face as the tide allowed sampling.

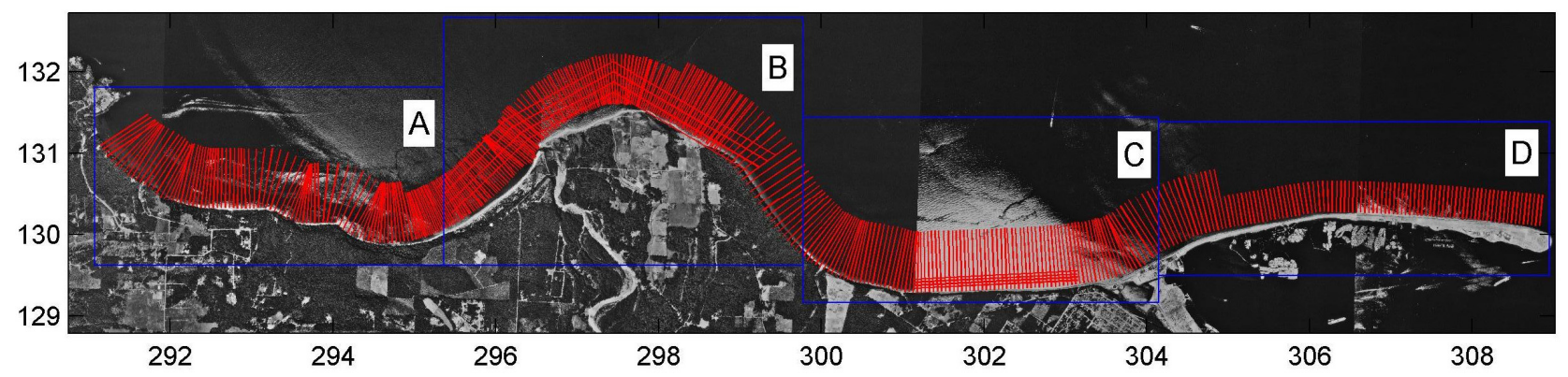

Figure $2 \underline{A}$. Elwha profile lines shown in red for the entire study area. Inset regions for figures $2 \underline{B}-\underline{E}$ are shown with blue boxes and labeled by A-D. Axes are Washington State Plane North (km). 


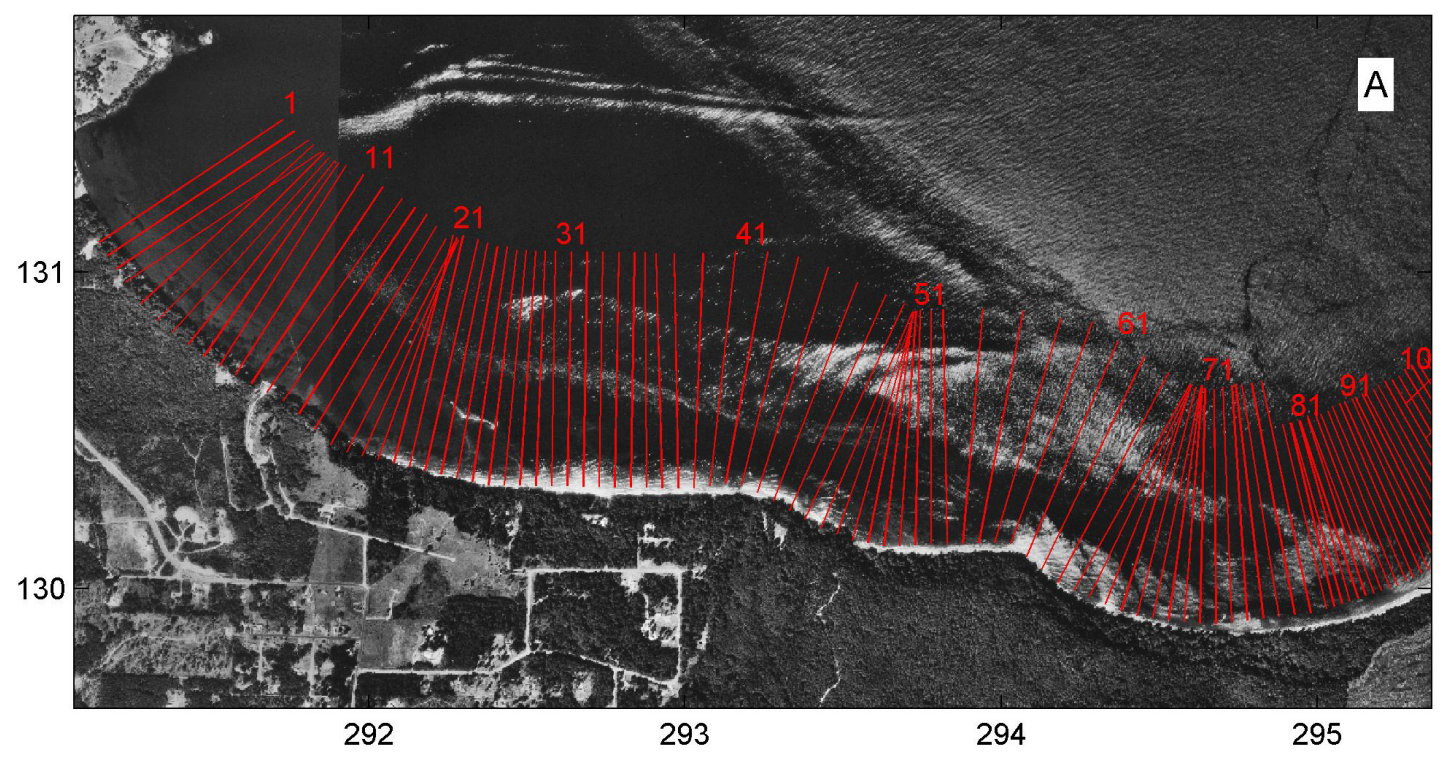

Figure $2 \underline{B}$. Elwha profile lines for the Freshwater Bay portion of the study area. Every tenth line is labeled with the corresponding line number. Axes are Washington State Plane North $(\mathrm{km})$. 


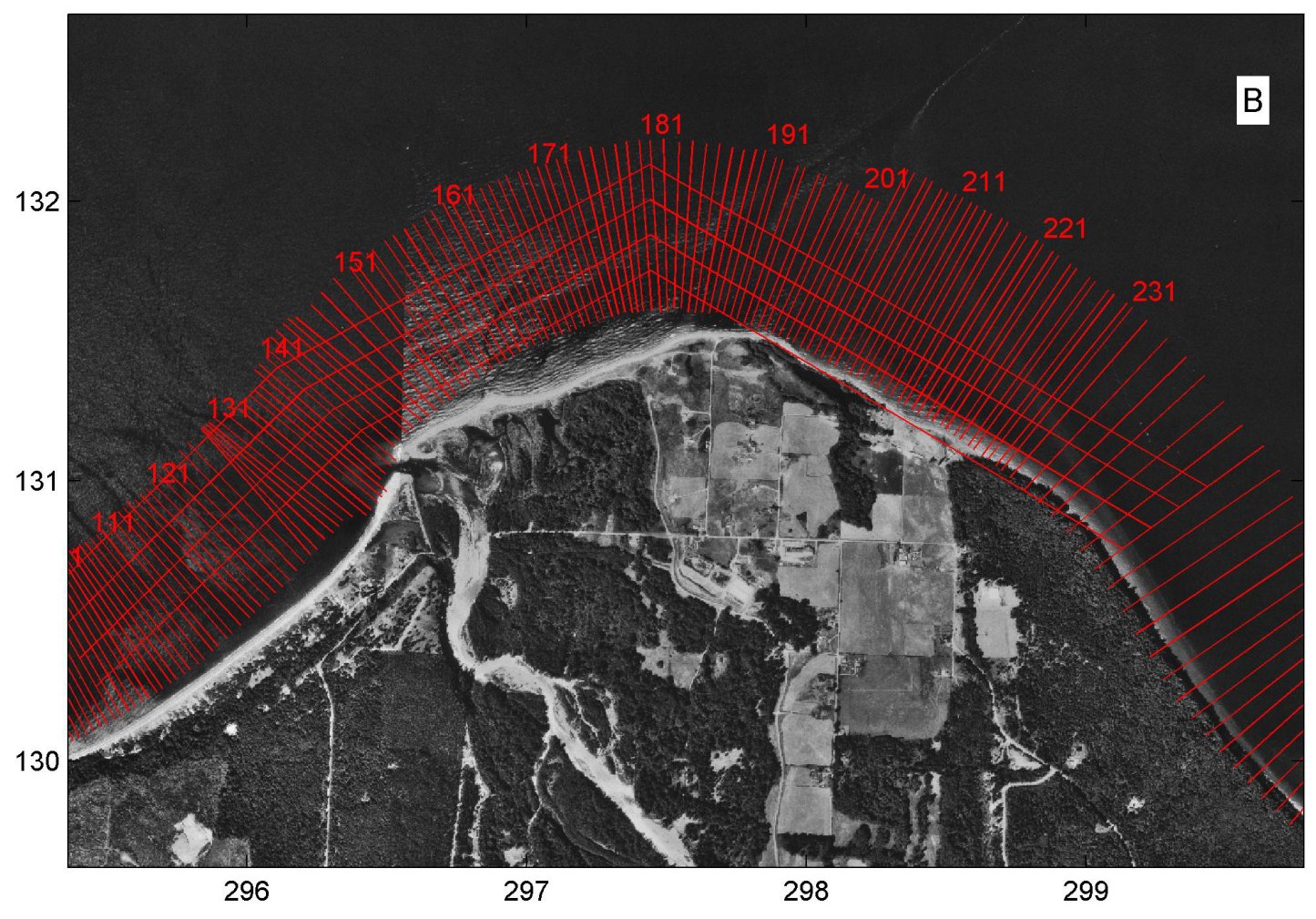

Figure $2 \underline{C}$. Elwha profile lines for the delta-region portion of the study area. Every tenth line is labeled with the corresponding line number. Axes are Washington State Plane North (km). 


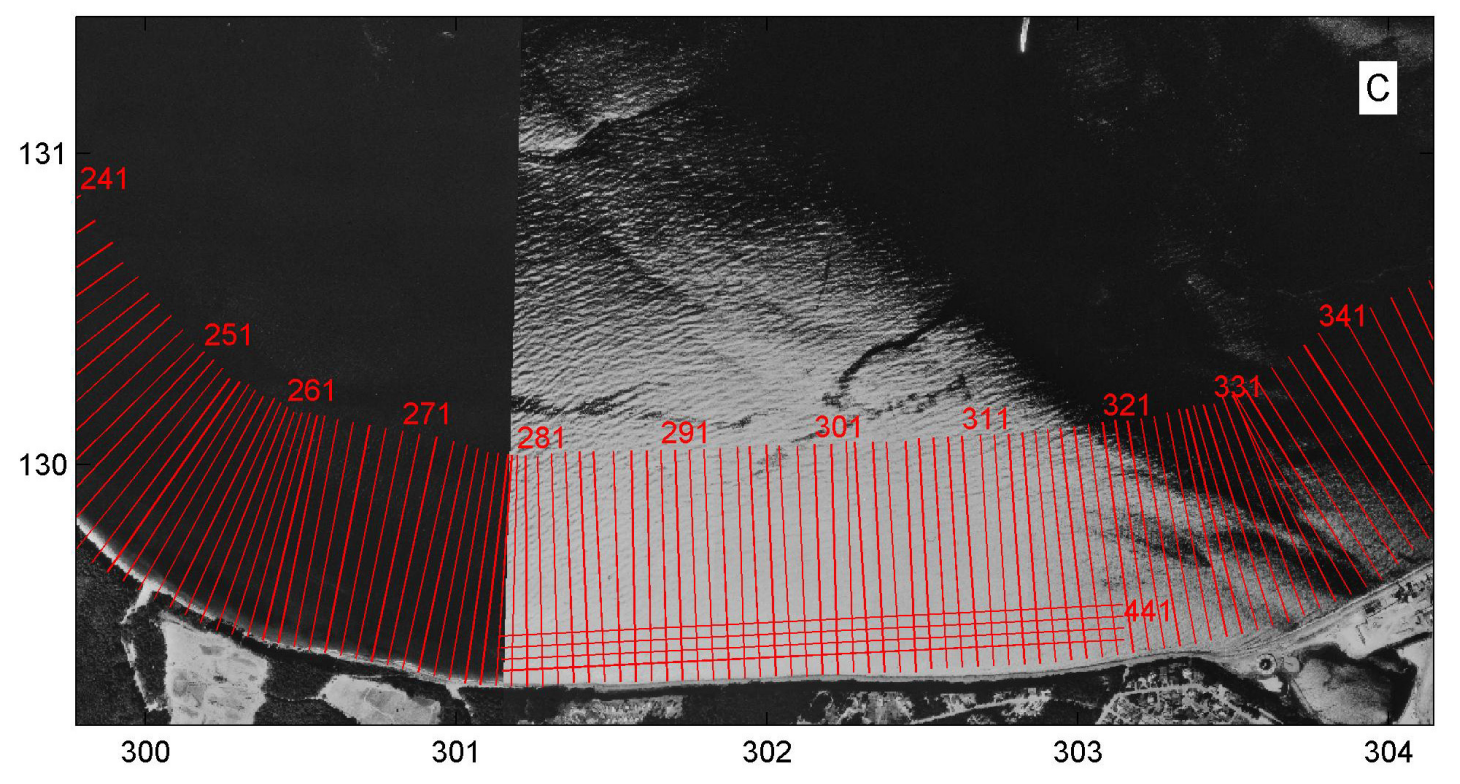

Figure 2 $\underline{D}$. Elwha profile lines for the east delta portion of the study area. Every tenth line is labeled with the corresponding line number. Axes are Washington State Plane North ( $\mathrm{km})$.

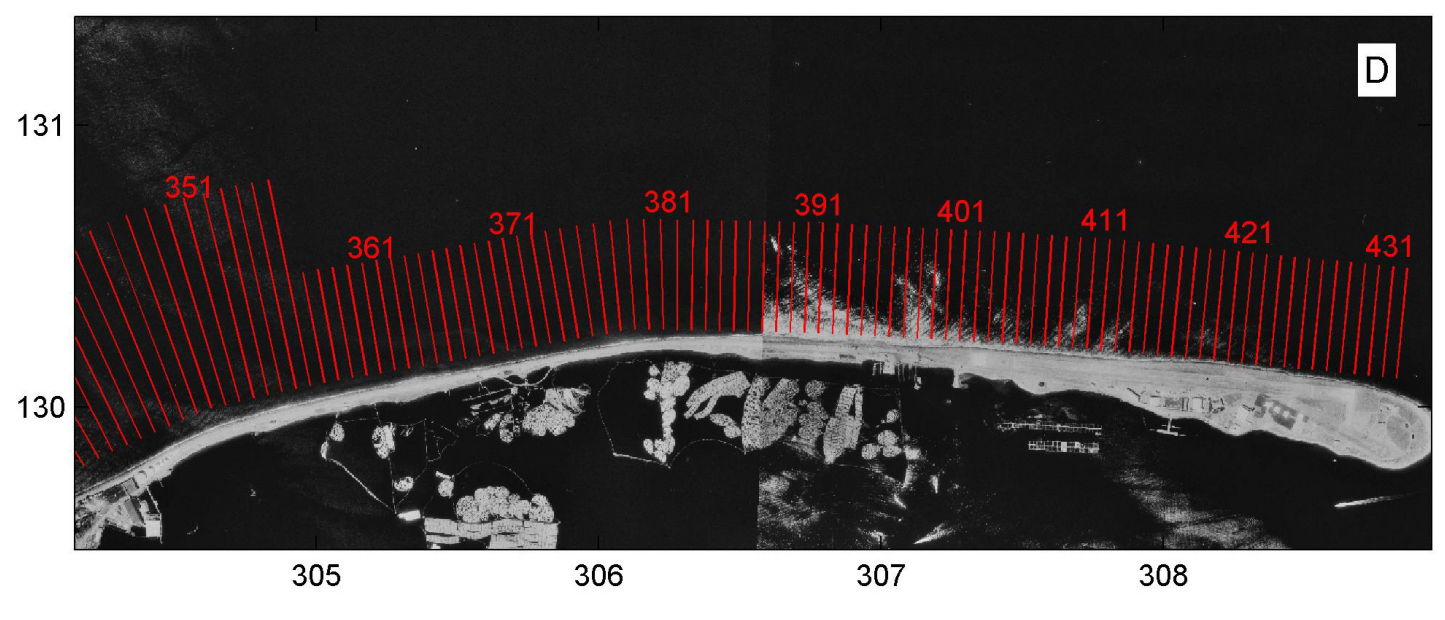

Figure 2E. Elwha Planned Lines for the Ediz Hook portion of the study area. Every tenth line is labeled with the corresponding line number. Axes are Washington State Plane North $(\mathrm{km})$. 


\section{Data Processing}

\section{Topography Data}

The topographic profiles were exported from the handheld GPS unit and calibrated into the geodetic network by using Trimble Geomatics Software. Quantities important to data quality were checked for errors during this operation. As the topographic data were much less dense than the bathymetric profiles, no smoothing was required. One data file per transect was saved as an Easting, Northing, Elevation (x, y, z) ASCII triplet in Washington State Plane North (NAD 83) and NAVD 88.

\section{Bathymetry Data}

Each individual bathymetric transect was examined to detect and remove any obvious outliers from the raw files that were either shallower than the echo sounder blanking interval or deeper than a user-defined cutoff value. Individual files were then exported in Easting, Northing, Elevation (x, y, z) ASCII triplets with one data file per transect in Washington State Plane North (NAD 83) and NAVD 88.

The sound velocity in seawater varies in the water column depending on water density, which is a function of salinity and temperature. The variability affects the echosounder travel time from the sensor to the bed and hence, the computed elevation. Large variabilities in seawater temperature $\left(\sim 10^{\circ} \mathrm{C}\right)$ can affect depth estimates by as much as $20 \mathrm{~cm}$ in $12 \mathrm{~m}$ of water. To correct for this phenomenon, a constant salinity of 31 practical salinity units (psu) was assumed, and water temperature at the time of data collection was derived from an average of daily temperatures recorded by at National Data Buoy Center (NDBC) Station 46088 in New Dungeness, Wash. This station is the nearest active buoy at approximately $40 \mathrm{~km}$ from the Elwha River delta. The water-density correction was conducted by using accepted algorithms for calculation of sound velocity in seawater (Fofonoff and Millard Jr., 1983). In addition to water temperature, other meteorological and marine conditions (for example, wave height 
and period, wind speed and direction, air temperature and barometric pressure) also were extracted from NDBC Station 46088 during the dates and times of sampling and saved as spreadsheet files.

A smoothing operation was then performed on the corrected bathymetric data by using a LOWESS (Cleveland, 1979) filter on the z-coordinate in the alongline direction to reduce highfrequency fluctuations from interferences, such as seaweed, and the effect of vehicle pitch and roll on the bed elevation. A moving, non-overlapping window size of seven data points was used, regardless of the length of the profile line. A simple polynomial regression function was used to extrapolate data at both ends of the line where less than seven data points exist. In a small number of profiles, the LOWESS filter could not resolve short segments of the seabed due to poor echsounder returns. The data were removed from these areas of the profiles while the remaining sections were processed with the filtering algorithm.

\section{Finished Products}

The following data are supplied on the online USGS Data Series Report at http://pubs.usgs.gov/ds/288/data/. Data can be obtained by using an Internet browser and the following directory structure.

\section{Bathymetric/Topographic Profile Data Files}

One data file exists for each final collected bathymetry line in the directory structure: data_\{year of survey $] /\{$ month of survey $\} /$ bathy/ew $\{$ year of survey $\} \_$line $\{$number $\} \_b . x y z$. For example, Line 151, collected in September 2006, can be found at data_06/septb/bathy/ew06_line151_b.xyz. Each file contains easting, northing, and elevation values in the coordinate system Washington State Plane North NAD $83(\mathrm{~m})$. Elevation data are represented in meters, NAVD 88, as this was the datum of the benchmark control point used in the survey. One data file for each collected topography line also is presented in the directory structure: data_\{year of survey $] /\{$ month of survey $\} /$ topo/ew $\{$ year of 
survey $\}_{\_}$line $\{$number $\} \_t . x y z$. The topography data files are in the same format and coordinate system as the bathymetric data files.

The individual bathymetric and topographic profiles can be combined to examine how successful the lines align and data overlap. For example, the bathymetric and topographic profiles of Line 151, collected September 2006, show reasonably good alignment and overlap (fig. 3).

\section{Metadata}

Metadata is included for all bathymetry and topography data collected at the Elwha River mouth. Data for the environmental-condition files were extracted from NDBC, and the headers for the data can be found in table 2 .

Table 2. Standard meteorological-data headers for NDBC files.

ATMP Air temperature (Celsius). For sensor heights on buoys, see Hull Descriptions. For sensor heights at C-MAN stations, see C-MAN Sensor Locations

WTMP Sea surface temperature (Celsius). For sensor depth, see Hull Description.

DEWP Dewpoint temperature taken at the same height as the air-temperature measurement.

PRES Sea-level pressure (hPa). For C-MAN sites and Great Lakes buoys, the recorded pressure is reduced to sea level by using the method described in NWS Technical Procedures Bulletin 291 (11/14/80).

WSPD Wind speed (m/s) averaged during an eight-minute period for buoys and a two-minute period for land stations. Reported hourly. See Wind Averaging Methods.

WDIR Wind direction (the direction the wind is coming from in degrees clockwise from true N) during the same period used for WSPD. See Wind Averaging Methods

GST Peak 5- or 8-second gust speed (m/s) measured during the eight-minute or two-minute period. The 5- or 8-second period can be determined by payload. See the Sensor Reporting, Sampling, and Accuracy section.

WVHT Significant wave height (meters) is calculated as the average of the highest one-third of all of the wave heights during the 20-minute sampling period. See the Wave Measurements section.

DPD Dominant wave period (seconds) is the period with the maximum wave energy. See the Wave Measurements section.

MWD Mean wave direction corresponding to energy of the dominant period (DOMPD). The units are degrees from true North just like wind direction. See the Wave Measurements section.

VIS Station visibility (statute miles). Note that buoy stations are limited to reports from 0 to 1.9 miles.

PTDY Pressure tendency is the direction (plus or minus) and the amount of pressure change (hPa) for a three-hour period ending at the time of observation.

Source: http://www.ndbc.noaa.gov/measdes.shtml 

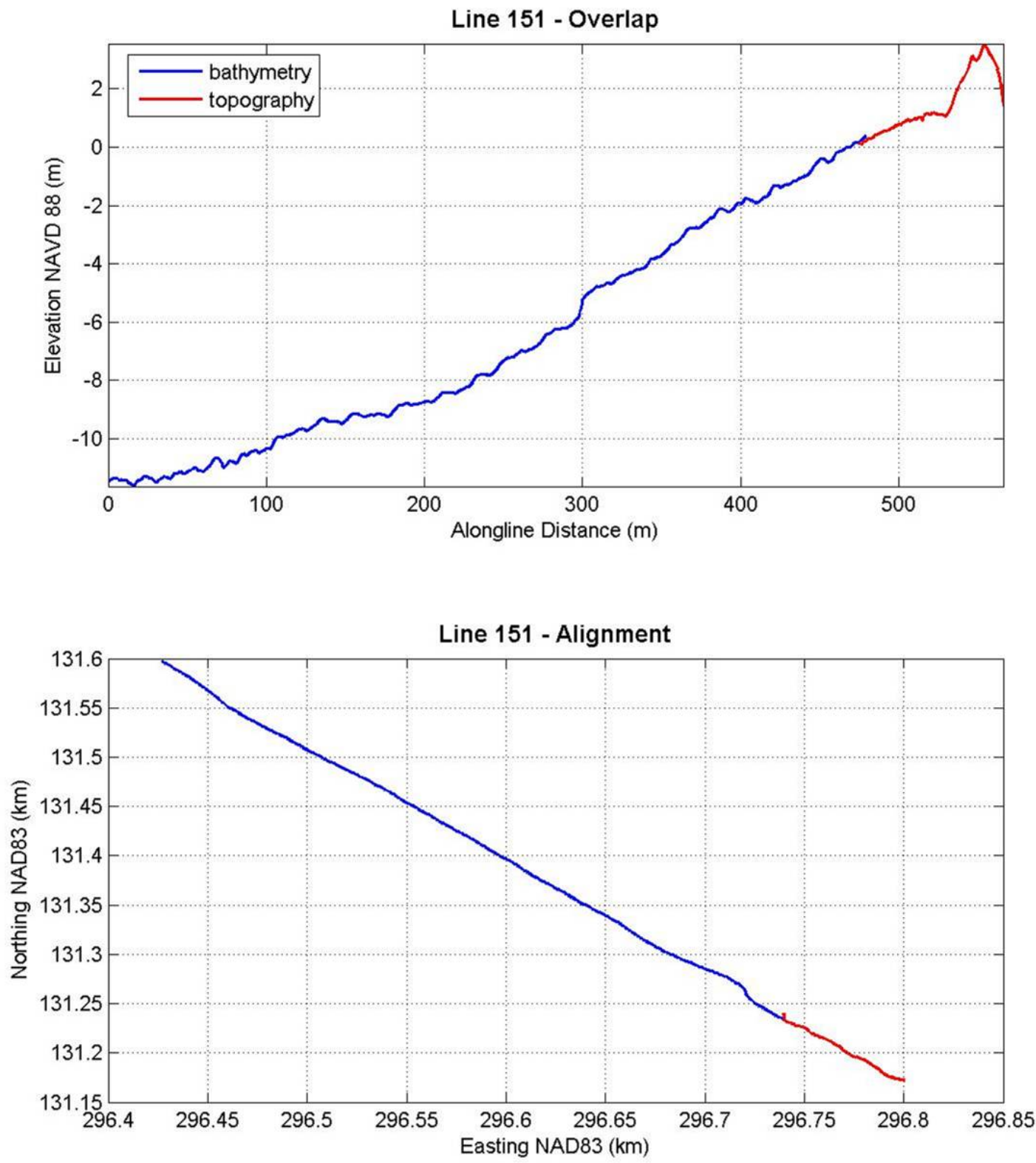

Figure 3. Overlap and alignment of bathymetric and topographic Line 151, September 2006. 


\section{Literature Cited}

Childers, D., Kresch, D.L., Gustafson, A.S., Randle, T.J., Melena, J.T. and Cluer, B., 2000, Hydrologic data collected during the 1994 Lake Mills drawdown experiment, Elwha River, Washington: U.S. Geological Survey Water-Resources Investigations Report 99-4215, 115 p.

Cleveland, W.S., 1979, Robust locally weighted regression and smoothing scatterplots: Journal of the American Statistical Association, v. 74, p. 829-836.

Finlayson D.P., Haugerud R.A., Greenberg, H. and Logsdon, M.G., 2000, Puget Sound digital elevation model: University of Washington, http://www.ocean.washington.edu/data/pugetsound/ (last accessed May 28, 2008).

Fofonoff, N.P. and Millard Jr., R.C., 1983, Algorithms for computation of fundamental properties of seawater: UNESCO Technical Paper in Marine Science, 44, 58 p.

MacMahan, J., 2001, Hydrographic surveying from a personal watercraft: Journal of Surveying Engineering, v. 127, no. 1, p. 12-24.

Olympic National Park, 1996, Elwha River ecosystem restoration implementation, Final Environmental Impact Statement: Port Angeles, Wash., U.S. National Park Service, http://www.nps.gov/olym/naturescience/upload/ElwhaFinalEIS2.pdf (last accessed May 28, 2008).

Randle, T.J., Young, C.A., Melena, J.T., and Ouellette, E.M., 1996, Sediment analysis and modeling of the river erosion alternative: U.S. Department of the Interior, Bureau of Reclamation, Elwha Technical Series PN-95-9, 138 p.

Ruggiero, P., Kaminsky, G.M., Gelfenbaum, G., and Voigt, B., 2005, Seasonal to interannual morphodynamic variability along a high-energy dissipative littoral cell: Journal of Coastal Research, v. 21, no. 3, p. 553-578.

Sallenger, A.H., Krabill, W.B., Swift, R.N., Brock, J., List, J., Hansen, M., Holman, R.A., Manizade, S., Sontag, J., Meredith, A., Morgan, K., Yunkel, J.K., Frederick, E.B., and Stockdon, H., 2003, 
Evaluation of airborne topographic lidar for quantifying beach changes: Journal of Coastal Research, v. 19, no. 1, p. 125-133.

Trimble Navigation Limited, 1998, 4700 Receiver operation manual, Version 1.0, Part Number 3623800, Revision B. 


\section{Appendix A - September 2004 Field Collection}

In September 2004, profiles were collected spanning a 16-km stretch from Freshwater Bay to Ediz Hook. Several alongshore bathymetric lines also were driven around the delta to serve as a crosscheck for data accuracy. Some additional alongshore lines were collected near Easting $302 \mathrm{~km}$ to try to resolve sand waves that were observed in sonar data collected in that region. On September 7-9, 119 bathymetric and 52 topographic profiles were collected between line 1 on the west and line 430 on the east at varying spacing intervals (figs. A1-A2). Bathymetric and topographic lines are enumerated in Table A. Metadata for this field activity (W-2-04-PS) are available at:

http://walrus.wr.usgs.gov/infobank/w/w204ps/html/w-2-04-ps.meta.html.

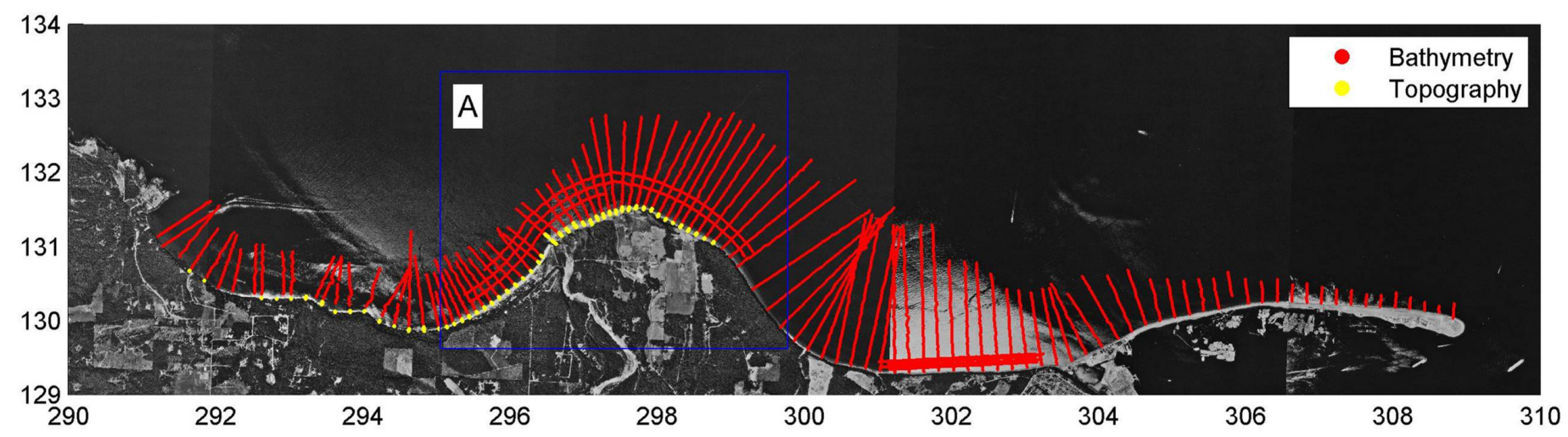

Figure A1. Elwha September 2004 surveyed lines. 


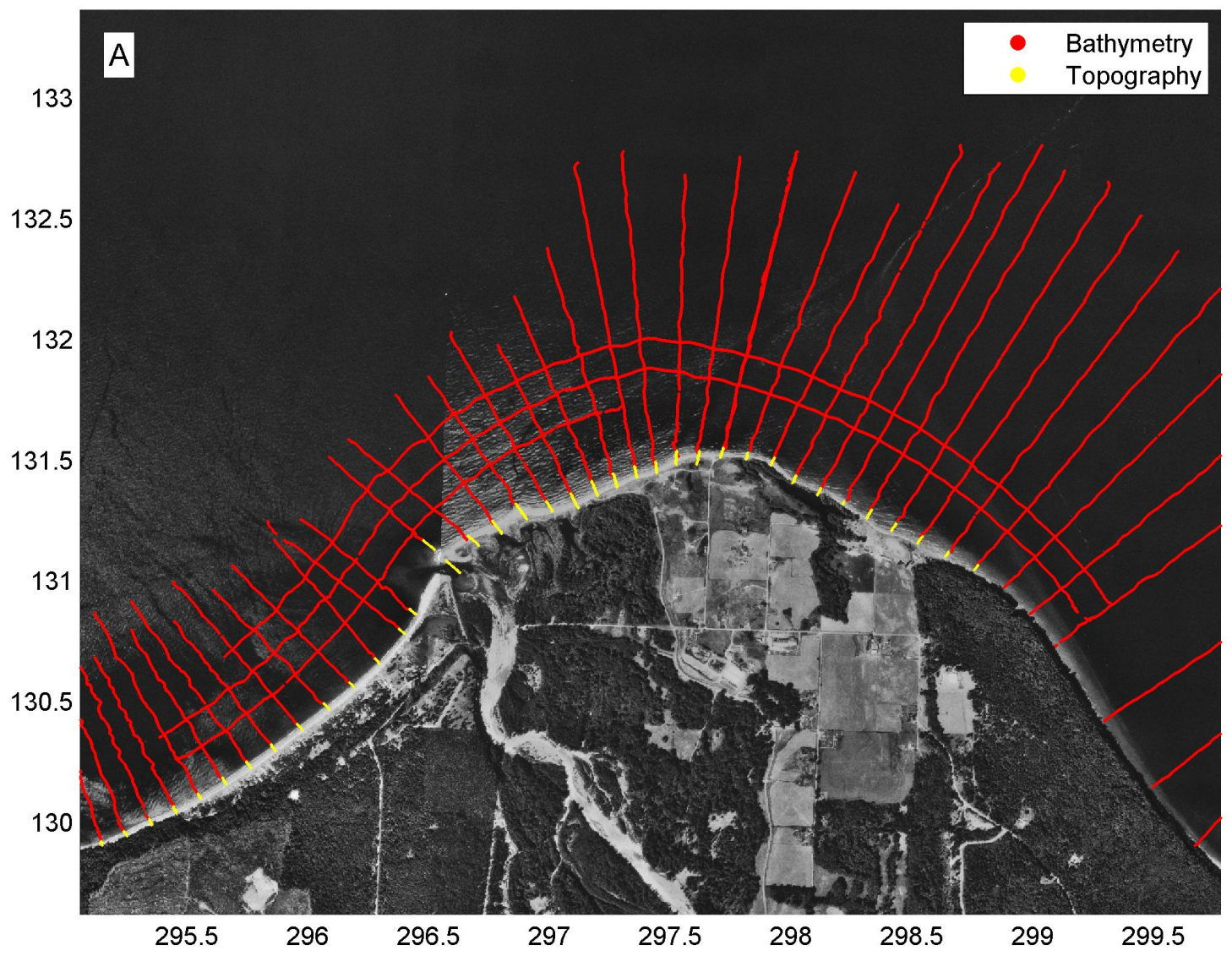

Figure A2. Elwha September 2004 surveyed lines (delta region).

Table A. Bathymetric and topographic lines for the September 2004 survey.

\begin{tabular}{|c|c|}
\hline Bathymetric line & Topographic line \\
\hline ew04_line001_b.xyz & \\
\hline ew04_line001_b2.xyz & \\
\hline ew04_line004_b.xyz & ew04_line012_t.xyz \\
\hline ew04_line008_b.xyz & ew04_line016_t.xyz \\
\hline ew04_line012_b.xyz & \\
\hline ew04_line016_b.xyz & \\
\hline ew04_line020_b.xyz & ew04_line032_t.xyz \\
\hline ew04_line024_b.xyz & ew04_line036_t.xyz \\
\hline ew04_line030_b.xyz & \\
\hline ew04_line032_b.xyz & ew04_line040_t.xyz \\
\hline & ew04_line044_t.xyz \\
\hline ew04_line038_b.xyz & \\
\hline ew04_line040_b.xyz &
\end{tabular}




\begin{tabular}{|c|c|}
\hline ew04_line048_b.xyz & ew04_line048_t.xyz \\
\hline ew04_line052_b.xyz & ew04_line052_t.xyz \\
\hline ew04_line056_b.xyz & ew04_line056_t.xyz \\
\hline ew04_line060_b.xyz & ew04_line060_t.xyz \\
\hline ew04_line064_b.xyz & ew04_line064_t.xyz \\
\hline ew04_line068_b.xyz & ew04_line068_t.xyz \\
\hline ew04_line072_b.xyz & ew04_line072_t.xyz \\
\hline ew04_line076_b.xyz & ew04_line076_t.xyz \\
\hline ew04_line080_b.xyz & ew04_line080_t.xyz \\
\hline ew04_line084_b.xyz & ew04_line084_t.xyz \\
\hline ew04_line088_b.xyz & ew04_line088_t.xyz \\
\hline ew04_line092_b.xyz & ew04_line092_t.xyz \\
\hline ew04_line096_b.xyz & ew04_line096_t.xyz \\
\hline ew04_line100_b.xyz & ew04_line100_t.xyz \\
\hline ew04_line104_b.xyz & ew04_line104_t.xyz \\
\hline ew04_line108_b.xyz & ew04_line108_t.xyz \\
\hline ew04_line112_b.xyz & ew04_line112_t.xyz \\
\hline ew04_line116_b.xyz & ew04_line116_t.xyz \\
\hline ew04_line120_b.xyz & ew04_line120_t.xyz \\
\hline ew04_line124_b.xyz & ew04_line124_t.xyz \\
\hline ew04_line128_b.xyz & ew04_line128_t.xyz \\
\hline ew04_line132_b.xyz & ew04_line132_t.xyz \\
\hline ew04_line135_b.xyz & ew04_line135_t.xyz \\
\hline ew04_line144_b.xyz & ew04_line144_t.xyz \\
\hline ew04_line148_b.xyz & ew04_line148_t.xyz \\
\hline ew04_line152_b.xyz & ew04_line152_t.xyz \\
\hline ew04_line156_b.xyz & ew04_line156_t.xyz \\
\hline ew04_line160_b.xyz & ew04_line160_t.xyz \\
\hline ew04_line164_b.xyz & ew04_line164_t.xyz \\
\hline ew04_line168_b.xyz & ew04_line168_t.xyz \\
\hline ew04_line172_b.xyz & ew04_line172_t.xyz \\
\hline ew04_line176_b.xyz & ew04_line176_t.xyz \\
\hline ew04 line 180 b.xyz & ew04 line 180 t.xyz \\
\hline ew04_line184_b.xyz & ew04_line184_t.xyz \\
\hline ew04_line188_b.xyz & ew04_line188_t.xyz \\
\hline ew04_line192_b.xyz & ew04_line192_t.xyz \\
\hline \multicolumn{2}{|l|}{ ew04_line192_b2.xyz } \\
\hline ew04_line196_b.xyz & ew04_line196_t.xyz \\
\hline ew04_line200_b.xyz & ew04_line200_t.xyz \\
\hline ew04_line204_b.xyz & ew04_line204_t.xyz \\
\hline ew04_line208_b.xyz & ew04_line208_t.xyz \\
\hline ew04_line212_b.xyz & ew04_line212_t.xyz \\
\hline ew04_line216_b.xyz & ew04_line216_t.xyz \\
\hline ew04_line220_b.xyz & ew04_line220_t.xyz \\
\hline ew04_line224_b.xyz & ew04_line224_t.xyz \\
\hline ew04_line228_b.xyz & ew04_line228_t.xyz \\
\hline ew04_line232_b.xyz & ew04_line232_t.xyz \\
\hline ew04_line234_b.xyz & \\
\hline ew04_line236_b.xyz & \\
\hline ew04_line238_b.xyz & \\
\hline ew04_line242_b.xyz & \\
\hline ew04_line246_b.xyz & \\
\hline ew04_line250_b.xyz & \\
\hline ew04_line254_b.xyz & \\
\hline ew04_line258_b.xyz & \\
\hline
\end{tabular}




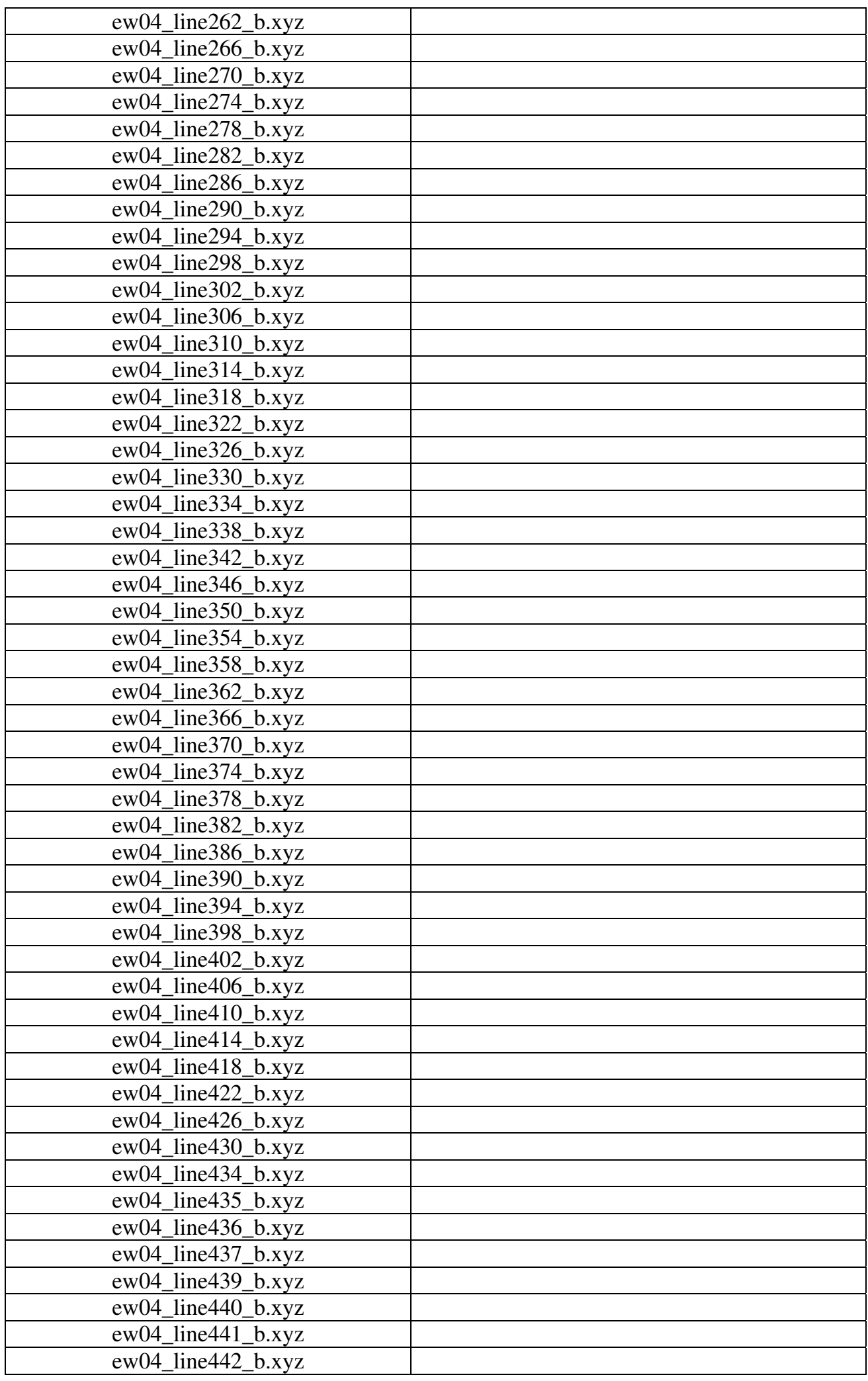




\section{Appendix B - March 2005 Field Collection}

For the March 2005 survey, the focus was shifted to resolving the delta at the river mouth in greater detail. On March 15-17, 75 bathymetric and 61 topographic profiles were collected between lines 92 on the west and 232 on the east (figs. B1-B2). Two alongshore bathymetric profiles also were collected. Bathymetric and topographic lines are enumerated in table B. Metadata for this field activity (W-1-05-PS) are available at: http://walrus.wr.usgs.gov/infobank/w/w105ps/html/w-1-05-ps.meta.html.

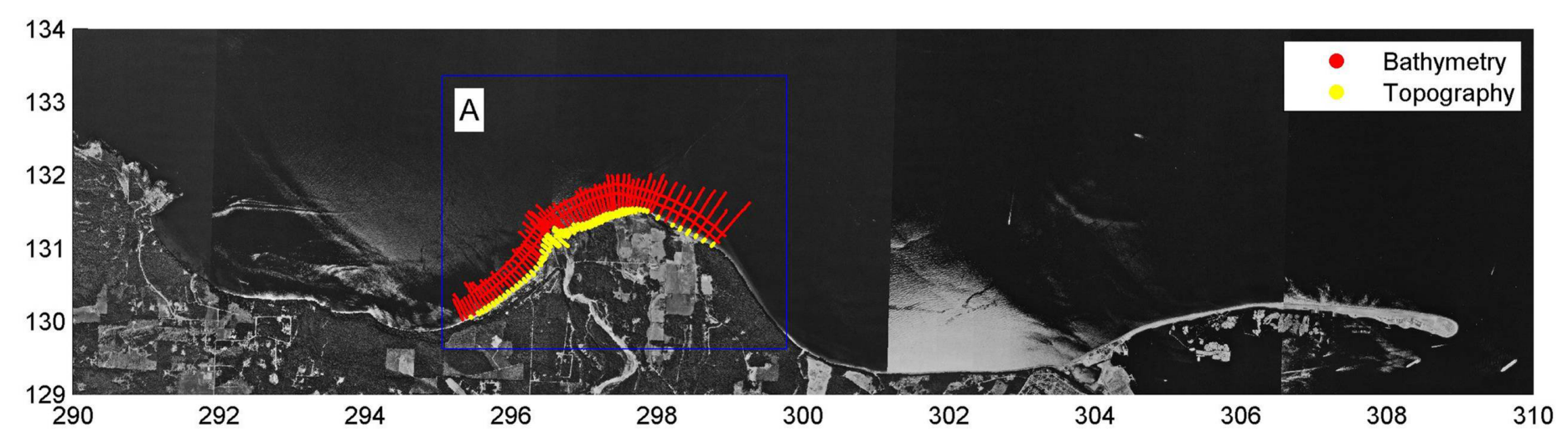

Figure B1. Elwha March 2005 surveyed lines. 


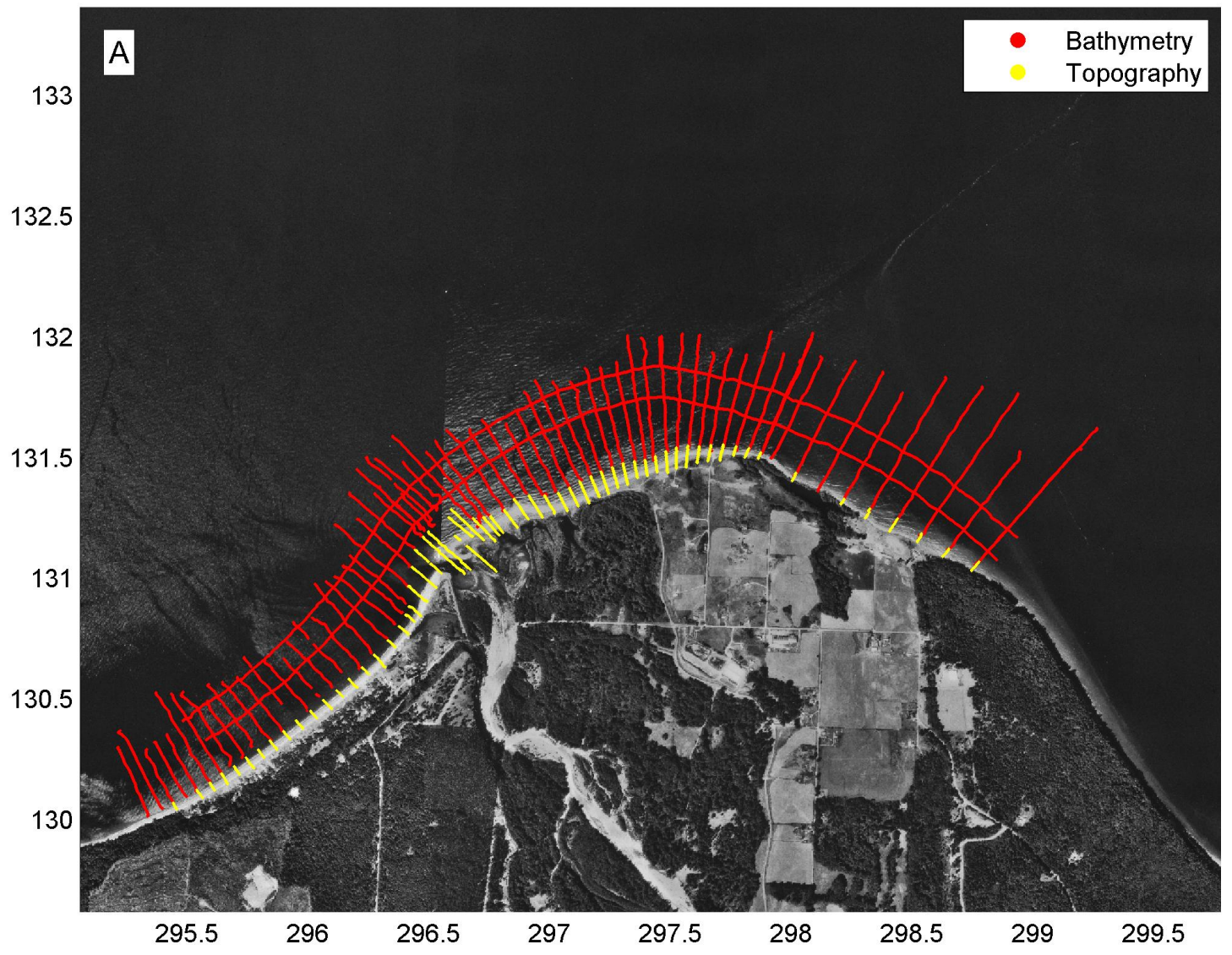

Figure B2. Elwha March 2005 surveyed lines (delta region).

Table B. Bathymetric and topographic lines for the March 2005 survey.

\begin{tabular}{|c|c|}
\hline Bathymetric line & Topographic line \\
\hline ew05_line092_b.xyz & \\
\hline ew05_line094_b.xyz & ew05_line096_t.xyz \\
\hline ew05_line096_b.xyz & \\
\hline ew05_line098_b.xyz & ew05_line100_t.xyz \\
\hline ew05_line100_b.xyz & ew05_line102_t.xyz \\
\hline ew05_line102_b.xyz & ew05_line104_t.xyz \\
\hline ew05_line104_b.xyz & ew05_line106_t.xyz \\
\hline ew05_line106_b.xyz & ew05_line108_t.xyz \\
\hline ew05_line108_b.xyz & ew05_line110_t.xyz \\
\hline ew05_line110_b.xyz & ew05_line112_t.xyz \\
\hline ew05_line112_b.xyz & ew05_line114_t.xyz \\
\hline ew05_line114_b.xyz & ew05_line116_t.xyz \\
\hline ew05_line116_b.xyz & ew05_line118_t.xyz \\
\hline ew05_line118_b.xyz & ew05_line120_t.xyz \\
\hline ew05_line120_b.xyz &
\end{tabular}




\begin{tabular}{|c|c|}
\hline ew05_line122_b.xyz & ew05_line122_t.xyz \\
\hline ew05_line124_b.xyz & ew05_line124_t.xyz \\
\hline ew05_line126_b.xyz & ew05_line126_t.xyz \\
\hline ew05_line128_b.xyz & ew05_line128_t.xyz \\
\hline ew05_line130_b.xyz & ew05_line130_t.xyz \\
\hline ew05_line132_b.xyz & ew05_line132_t.xyz \\
\hline ew05_line134_b.xyz & ew05_line134_t.xyz \\
\hline ew05_line135_b.xyz & ew05_line135_t.xyz \\
\hline ew05_line137_b.xyz & ew05_line137_t.xyz \\
\hline ew05_line140_b.xyz & ew05_line140_t.xyz \\
\hline ew05_line142_b.xyz & ew05_line142_t.xyz \\
\hline ew05_line144_b.xyz & ew05_line144_t.xyz \\
\hline ew05_line145_b.xyz & ew05_line145_t.xyz \\
\hline \multicolumn{2}{|l|}{ ew05_line145_b2.xyz } \\
\hline \multicolumn{2}{|l|}{ ew05_line146_b.xyz } \\
\hline ew05_line147_b.xyz & ew05_line147_t.xyz \\
\hline ew05_line148_b.xyz & ew05_line148_t.xyz \\
\hline ew05_line149_b.xyz & ew05_line149_t.xyz \\
\hline ew05_line150_b.xyz & ew05_line150_t.xyz \\
\hline \multicolumn{2}{|l|}{ ew05_line150_b2.xyz } \\
\hline ew05_line151_b.xyz & ew05_line151_t.xyz \\
\hline ew05_line152_b.xyz & ew05_line152_t.xyz \\
\hline ew05_line154_b.xyz & ew05_line154_t.xyz \\
\hline ew05_line156_b.xyz & ew05_line156_t.xyz \\
\hline ew05_line158_b.xyz & ew05_line158_t.xyz \\
\hline ew05_line160_b.xyz & ew05_line160_t.xyz \\
\hline ew05_line162_b.xyz & ew05_line162_t.xyz \\
\hline ew05_line164_b.xyz & ew05_line164_t.xyz \\
\hline ew05_line166_b.xyz & ew05_line166_t.xyz \\
\hline ew05_line168_b.xyz & ew05_line168_t.xyz \\
\hline ew05_line170_b.xyz & ew05_line170_t.xyz \\
\hline ew05_line172_b.xyz & ew05_line172_t.xyz \\
\hline ew05_line174_b.xyz & ew05_line174_t.xyz \\
\hline ew05_line176_b.xyz & ew05_line176_t.xyz \\
\hline ew05_line178_b.xyz & ew05_line178_t.xyz \\
\hline ew05_line180_b.xyz & ew05_line180_t.xyz \\
\hline ew05_line182_b.xyz & ew05_line182_t.xyz \\
\hline \multicolumn{2}{|l|}{ ew05_line182_b2.xyz } \\
\hline ew05_line184_b.xyz & ew05_line184_t.xyz \\
\hline ew05_line186_b.xyz & ew05_line186_t.xyz \\
\hline ew05_line188_b.xyz & ew05_line188_t.xyz \\
\hline ew05_line190_b.xyz & ew05_line190_t.xyz \\
\hline ew05_line192_b.xyz & ew05_line192_t.xyz \\
\hline ew05_line194_b.xyz & ew05_line194_t.xyz \\
\hline ew05_line196_b.xyz & ew05_line196_t.xyz \\
\hline ew05_line198_b.xyz & ew05_line198_t.xyz \\
\hline \multicolumn{2}{|l|}{ ew05_line198_b2.xyz } \\
\hline \multicolumn{2}{|l|}{ ew05_line198_b3.xyz } \\
\hline \multicolumn{2}{|l|}{ ew05_line200_b.xyz } \\
\hline ew05_line204_b.xyz & ew05_line204_t.xyz \\
\hline \multicolumn{2}{|l|}{ ew05_line208_b.xyz } \\
\hline ew05_line212_b.xyz & ew05_line212_t.xyz \\
\hline ew05_line216_b.xyz & ew05_line216_t.xyz \\
\hline ew05_line220_b.xyz & ew05_line220_t.xyz \\
\hline ew05_line224_b.xyz & ew05_line224_t.xyz \\
\hline
\end{tabular}




\begin{tabular}{|c|c|}
\hline ew05_line228_b.xyz & ew05_line228_t.xyz \\
\hline ew05_line232_b.xyz & ew05_line232_t.xyz \\
\hline ew05_line232_b2.xyz & \\
\hline ew05_line435_b.xyz & \\
\hline ew05_line436_b.xyz & \\
\hline
\end{tabular}




\section{Appendix C - August-September 2005 Field Collection}

In Fall 2005, a broader sampling was attempted. On August 30-September 1, 101 bathymetric profiles and 74 topographic profiles were collected from the Elwha River delta between line numbers 8 to the west and 402 to the east (figs. C1-C2). Two alongshore bathymetric profiles also were collected. Bathymetric and topographic lines are enumerated in table C. Metadata for this field activity (W-2-05PS) are available at: http://walrus.wr.usgs.gov/infobank/w/w205ps/html/w-2-05-ps.meta.html.

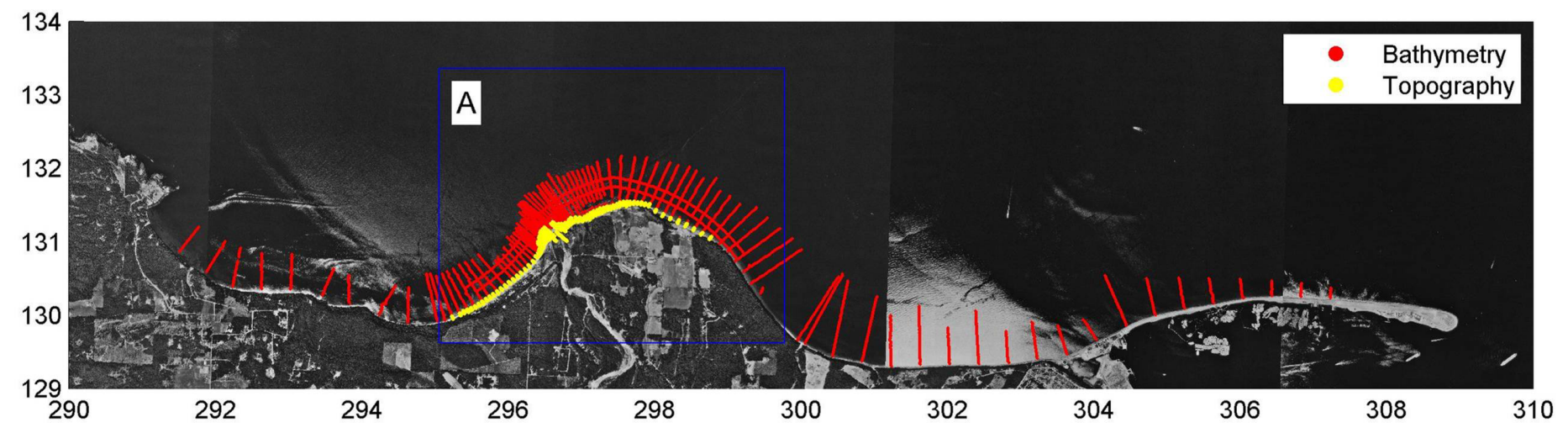

Figure C1. Elwha August-September 2005 surveyed lines. 


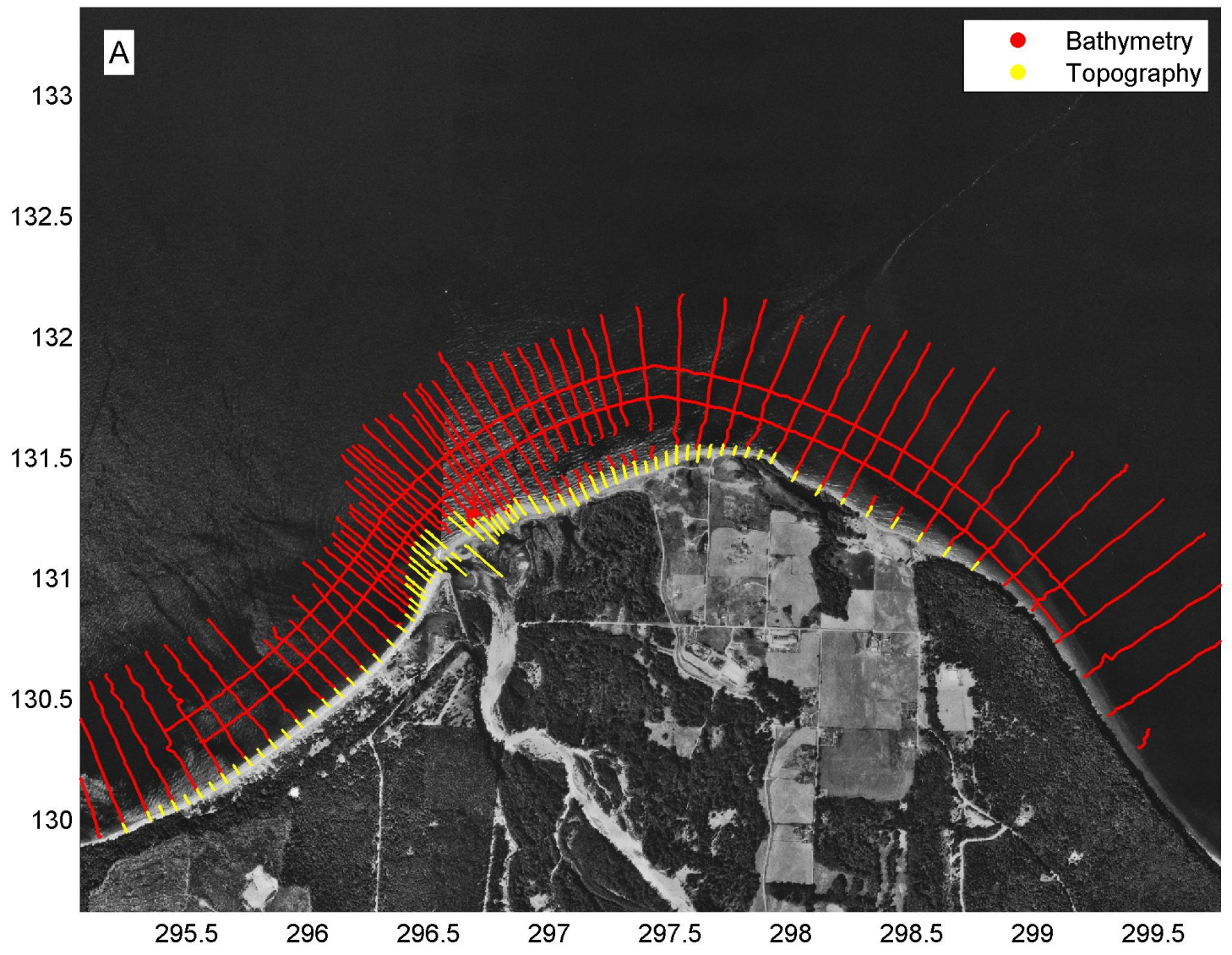

Figure C2. Elwha August-September 2005 surveyed lines (delta region).

Table C. Bathymetric and topographic lines for the August-September 2005 survey.

\begin{tabular}{|c|c|}
\hline Bathymetric line & Topographic line \\
\hline ew05_line008_b.xyz & \\
\hline ew05_line016_b.xyz & \\
\hline ew05_line024_b.xyz & \\
\hline ew05_line032_b.xyz & \\
\hline ew05_line040_b.xyz & \\
\hline ew05_line048_b.xyz & \\
\hline ew05_line056_b.xyz & \\
\hline ew05_line064_b.xyz & \\
\hline ew05_line072_b.xyz & \\
\hline ew05_line080_b.xyz & ew05_line088_t.xyz \\
\hline ew05_line084_b.xyz & ew05_line092_t.xyz \\
\hline ew05_line088_b.xyz & ew05_line094_t.xyz \\
\hline ew05_line092_b.xyz & ew05_line096_t.xyz \\
\hline &
\end{tabular}




\begin{tabular}{|c|c|}
\hline & ew05_line098_t.xyz \\
\hline \multirow[t]{2}{*}{ ew05_line100_b.xyz } & ew05_line100_t.xyz \\
\hline & ew05_line102_t.xyz \\
\hline \multirow[t]{2}{*}{ ew05_line104_b.xyz } & ew05_line104_t.xyz \\
\hline & ew05_line106_t.xyz \\
\hline \multirow[t]{2}{*}{ ew05_line108_b.xyz } & ew05_line108_t.xyz \\
\hline & ew05_line110_t.xyz \\
\hline \multirow[t]{2}{*}{ ew05_line112_b.xyz } & ew05_line112_t.xyz \\
\hline & ew05_line114_t.xyz \\
\hline \multirow[t]{2}{*}{ ew05_line116_b.xyz } & ew05_line116_t.xyz \\
\hline & ew05_line118_t.xyz \\
\hline ew05_line120_b.xyz & ew05_line120_t.xyz \\
\hline ew05_line122_b.xyz & ew05_line122_t.xyz \\
\hline ew05_line124_b.xyz & ew05_line124_t.xyz \\
\hline ew05_line126_b.xyz & ew05_line126_t.xyz \\
\hline ew05_line128_b.xyz & ew05_line128_t.xyz \\
\hline ew05_line130_b.xyz & ew05_line130_t.xyz \\
\hline ew05_line132_b.xyz & ew05_line132_t.xyz \\
\hline ew05_line134_b.xyz & ew05_line134_t.xyz \\
\hline ew05_line135_b.xyz & ew05_line135_t.xyz \\
\hline \multirow[t]{2}{*}{ ew05_line136_b.xyz } & ew05_line136_t.xyz \\
\hline & ew05_line136_t2.xyz \\
\hline ew05_line137_b.xyz & ew05_line137_t.xyz \\
\hline ew05_line138_b.xyz & ew05_line138_t.xyz \\
\hline ew05_line140_b.xyz & ew05_line140_t.xyz \\
\hline ew05_line141_b.xyz & ew05_line141_t.xyz \\
\hline ew05_line142_b.xyz & ew05_line142_t.xyz \\
\hline ew05_line143_b.xyz & ew05_line143_t.xyz \\
\hline ew05_line144_b.xyz & ew05_line144_t.xyz \\
\hline ew05_line145_b.xyz & ew05_line145_t.xyz \\
\hline \multicolumn{2}{|l|}{ ew05_line146_b.xyz } \\
\hline ew05_line147_b.xyz & ew05_line147_t.xyz \\
\hline ew05_line148_b.xyz & ew05_line148_t.xyz \\
\hline \multicolumn{2}{|l|}{ ew05_line148_b2.xyz } \\
\hline ew05_line149_b.xyz & ew05_line149_t.xyz \\
\hline ew05_line150_b.xyz & ew05_line150_t.xyz \\
\hline ew05_line151_b.xyz & ew05_line151_t.xyz \\
\hline ew05_line152_b.xyz & ew05_line152_t.xyz \\
\hline ew05_line153_b.xyz & ew05_line153_t.xyz \\
\hline ew05_line154_b.xyz & ew05_line154_t.xyz \\
\hline ew05_line155_b.xyz & ew05_line155_t.xyz \\
\hline ew05_line156_b.xyz & ew05_line156_t.xyz \\
\hline ew05_line158_b.xyz & ew05_line158_t.xyz \\
\hline ew05_line160_b.xyz & ew05_line160_t.xyz \\
\hline ew05_line162_b.xyz & ew05_line162_t.xyz \\
\hline ew05_line164_b.xyz & ew05_line164_t.xyz \\
\hline ew05_line166_b.xyz & ew05_line166_t.xyz \\
\hline ew05_line168_b.xyz & ew05_line168_t.xyz \\
\hline ew05_line170_b.xyz & ew05_line170_t.xyz \\
\hline ew05_line172_b.xyz & ew05_line172_t.xyz \\
\hline ew05_line174_b.xyz & ew05_line174_t.xyz \\
\hline \multirow[t]{2}{*}{ ew05_line176_b.xyz } & ew05_line176_t.xyz \\
\hline & ew05_line178_t.xyz \\
\hline \multirow[t]{2}{*}{ ew05_line180_b.xyz } & ew05_line180_t.xyz \\
\hline & ew05_line182_t.xyz \\
\hline
\end{tabular}




\begin{tabular}{|c|c|}
\hline ew05_line184_b.xyz & ew05_line184_t.xyz \\
\hline & ew05_line186_t.xyz \\
\hline ew05_line188_b.xyz & ew05_line188_t.xyz \\
\hline & ew05_line190_t.xyz \\
\hline ew05_line192_b.xyz & ew05_line192_t.xyz \\
\hline & ew05_line194_t.xyz \\
\hline ew05_line196_b.xyz & ew05_line196_t.xyz \\
\hline & ew05_line198_t.xyz \\
\hline ew05_line200_b.xyz & ew05_line200_t.xyz \\
\hline ew05_line204_b.xyz & ew05_line204_t.xyz \\
\hline ew05_line208_b.xyz & ew05_line208_t.xyz \\
\hline ew05_line212_b.xyz & ew05_line212_t.xyz \\
\hline ew05_line216_b.xyz & ew05_line216_t.xyz \\
\hline ew05_line220_b.xyz & ew05_line220_t.xyz \\
\hline ew05_line224_b.xyz & ew05_line224_t.xyz \\
\hline ew05_line228_b.xyz & ew05_line228_t.xyz \\
\hline ew05_line232_b.xyz & ew05_line232_t.xyz \\
\hline ew05_line234_b.xyz & \\
\hline ew05_line236_b.xyz & \\
\hline ew05_line238_b.xyz & \\
\hline ew05_line240_b.xyz & \\
\hline ew05_line242_b.xyz & \\
\hline ew05_line244_b.xyz & \\
\hline ew05_line256_b.xyz & \\
\hline ew05_line258_b.xyz & \\
\hline ew05_line266_b.xyz & \\
\hline ew05_line274_b.xyz & \\
\hline ew05_line282_b.xyz & \\
\hline ew05_line290_b.xyz & \\
\hline ew05_line298_b.xyz & \\
\hline ew05_line306_b.xyz & \\
\hline ew05_line314_b.xyz & \\
\hline ew05_line322_b.xyz & \\
\hline ew05_line330_b.xyz & \\
\hline ew05_line338_b.xyz & \\
\hline ew05_line346_b.xyz & \\
\hline ew05_line354_b.xyz & \\
\hline ew05_line362_b.xyz & \\
\hline ew05_line370_b.xyz & \\
\hline ew05_line378_b.xyz & \\
\hline ew05_line386_b.xyz & \\
\hline ew05_line394_b.xyz & \\
\hline ew05_line402_b.xyz & \\
\hline ew05_line435_b.xyz & \\
\hline ew05_line436_b.xyz & \\
\hline & \\
\hline & \\
\hline & \\
\hline & \\
\hline & \\
\hline & \\
\hline & \\
\hline & \\
\hline & \\
\hline & \\
\hline & \\
\hline & \\
\hline & \\
\hline & \\
\hline & \\
\hline & \\
\hline & \\
\hline & \\
\hline & \\
\hline & \\
\hline & \\
\hline & \\
\hline & \\
\hline & \\
\hline & \\
\hline & \\
\hline
\end{tabular}




\section{Appendix D - January 2006 Field Collection}

During January 2006, a special survey was conducted to characterize the coastal response to a large storm. A series of large storms and high tides during December 26, 2005, to January 5, 2006, produced coastal erosion and flooding along the delta east of the river mouth. Following this event, a survey was conducted during the low tides occurring during the nights and early mornings of January 11 and 12,2006 . Because this was a rapid-response survey, the watercraft-based bathymetric surveys could not be included. Further, the survey was conducted only along a 1-km stretch of beach in the region of greatest reported erosion and flooding. A total of 41 topographic profiles were obtained during this survey (USGS Field Activity W-S1-06-PS) at a spacing of 25 m (figure D1-D2). Topographic lines are enumerated in table D. Metadata for this field activity are available at: http://walrus.wr.usgs.gov/infobank/w/ws106ps/html/w-sl-06-ps.meta.html.

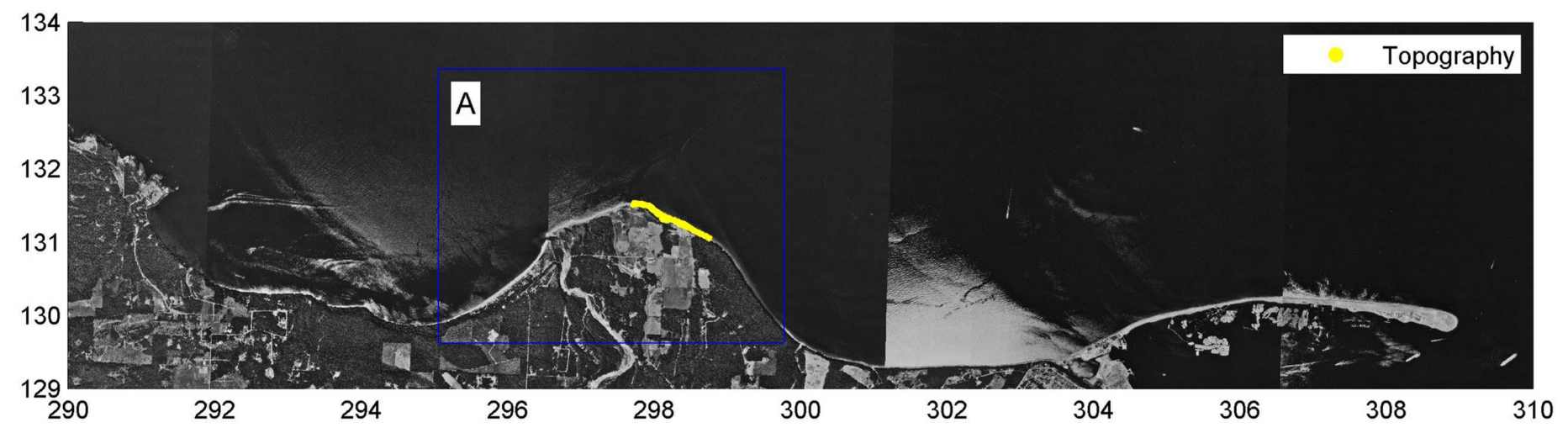

Figure D1. Elwha January 2006 surveyed lines. Only topography data were collected. 


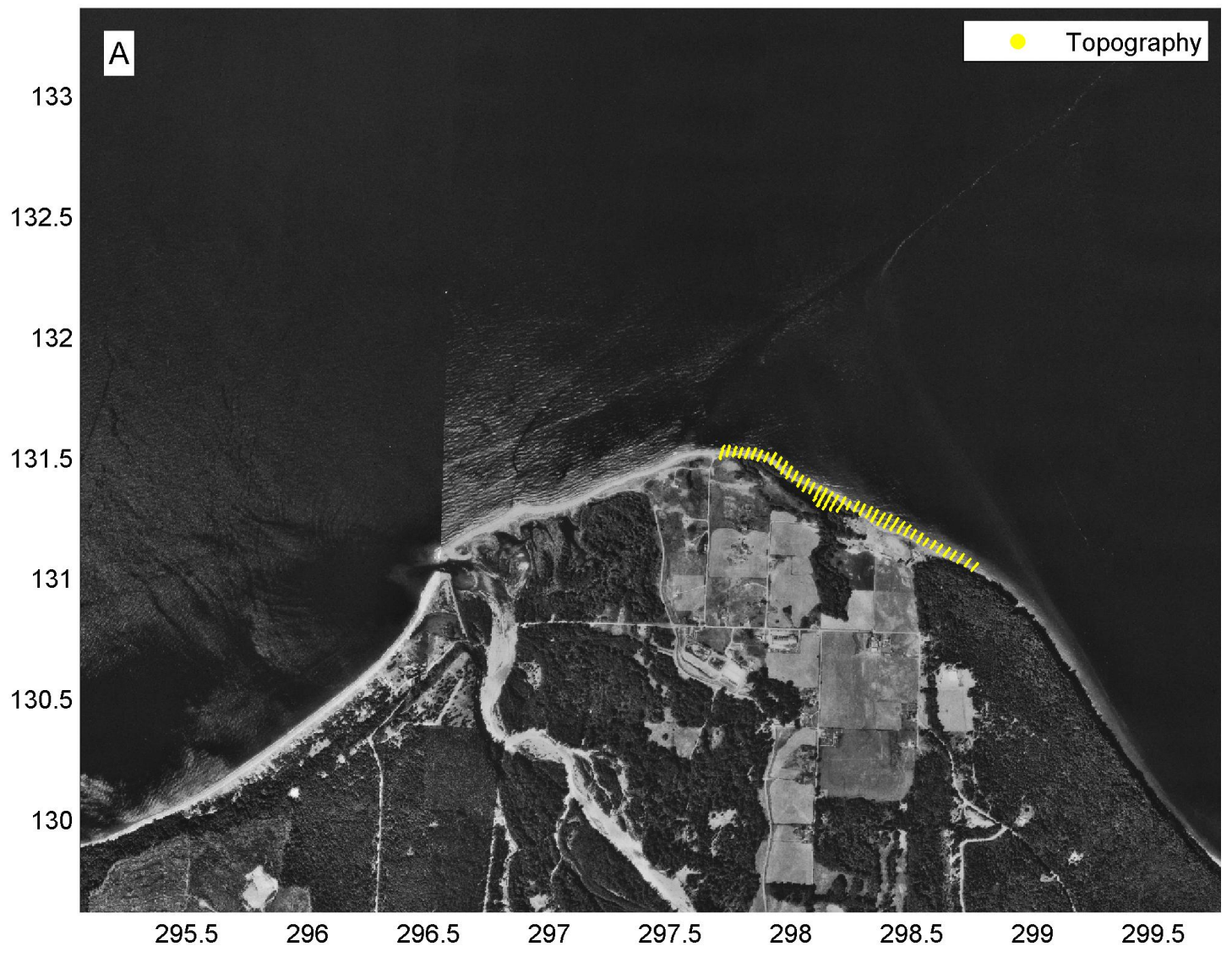

Figure D2. Elwha January 2006 surveyed lines (delta region). Only topography data were collected.

Table D. Topographic lines for the January 2006 survey.

\begin{tabular}{|l|}
\hline Topographic line \\
\hline ew06_line192_t.xyz \\
\hline ew06_line193_t.xyz \\
\hline ew06_line194_t.xyz \\
\hline ew06_line195_t.xyz \\
\hline ew06_line196_t.xyz \\
\hline ew06_line197_t.xyz \\
\hline ew06_line198_t.xyz \\
\hline ew06_line199_t.xyz \\
\hline ew06_line200_t.xyz \\
\hline ew06_line201_t.xyz \\
\hline ew06_line202_t.xyz \\
\hline ew06_line203_t.xyz \\
\hline ew06_line204_t.xyz \\
\hline ew06_line205_t.xyz \\
\hline ew06_line206_t.xyz \\
\hline
\end{tabular}




\begin{tabular}{|l|}
\hline ew06_line207_t.xyz \\
\hline ew06_line208_t.xyz \\
\hline ew06_line209_t.xyz \\
\hline ew06_line210_t.xyz \\
\hline ew06_line211_t.xyz \\
\hline ew06_line212_t.xyz \\
\hline ew06_line213_t.xyz \\
\hline ew06_line214_t.xyz \\
\hline ew06_line215_t.xyz \\
\hline ew06_line216_t.xyz \\
\hline ew06_line217_t.xyz \\
\hline ew06_line218_t.xyz \\
\hline ew06_line219_t.xyz \\
\hline ew06_line220_t.xyz \\
\hline ew06_line221_t.xyz \\
\hline ew06_line222_t.xyz \\
\hline ew06_line223_t.xyz \\
\hline ew06_line224_t.xyz \\
\hline ew06_line225_t.xyz \\
\hline ew06_line226_t.xyz \\
\hline ew06_line227_t.xyz \\
\hline ew06_line228_t.xyz \\
\hline ew06_line229_t.xyz \\
\hline ew06_line230_t.xyz \\
\hline ew06_line231_t.xyz \\
\hline ew06_line232_t.xyz \\
\hline
\end{tabular}




\section{Appendix E - April 2006 Field Collection}

No bathymetric data were collected during this survey due to unsafe weather, as the winds and waves were too large to sample the nearshore by watercraft. Topographic data were collected (table E), however, between lines 119 to 232 for a total of 110 profiles (figs. E1-E2). Metadata for this field activity (W-S2-06-PS) are available at: http://walrus.wr.usgs.gov/infobank/w/ws206ps/html/w-s2-06ps.meta.html.

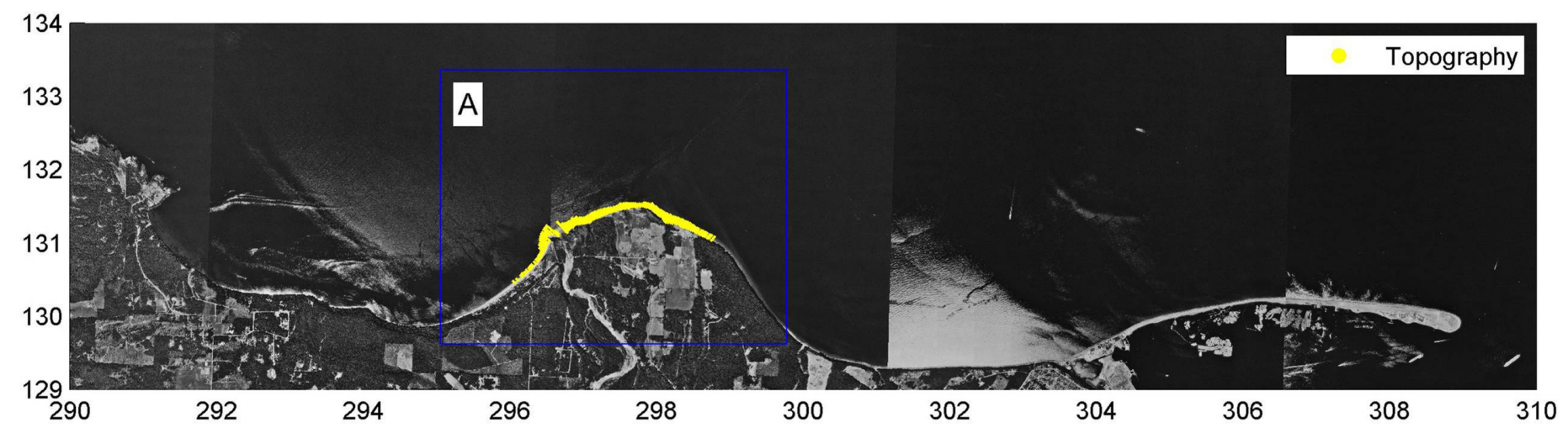

Figure E1. Elwha April 2006 surveyed lines. 


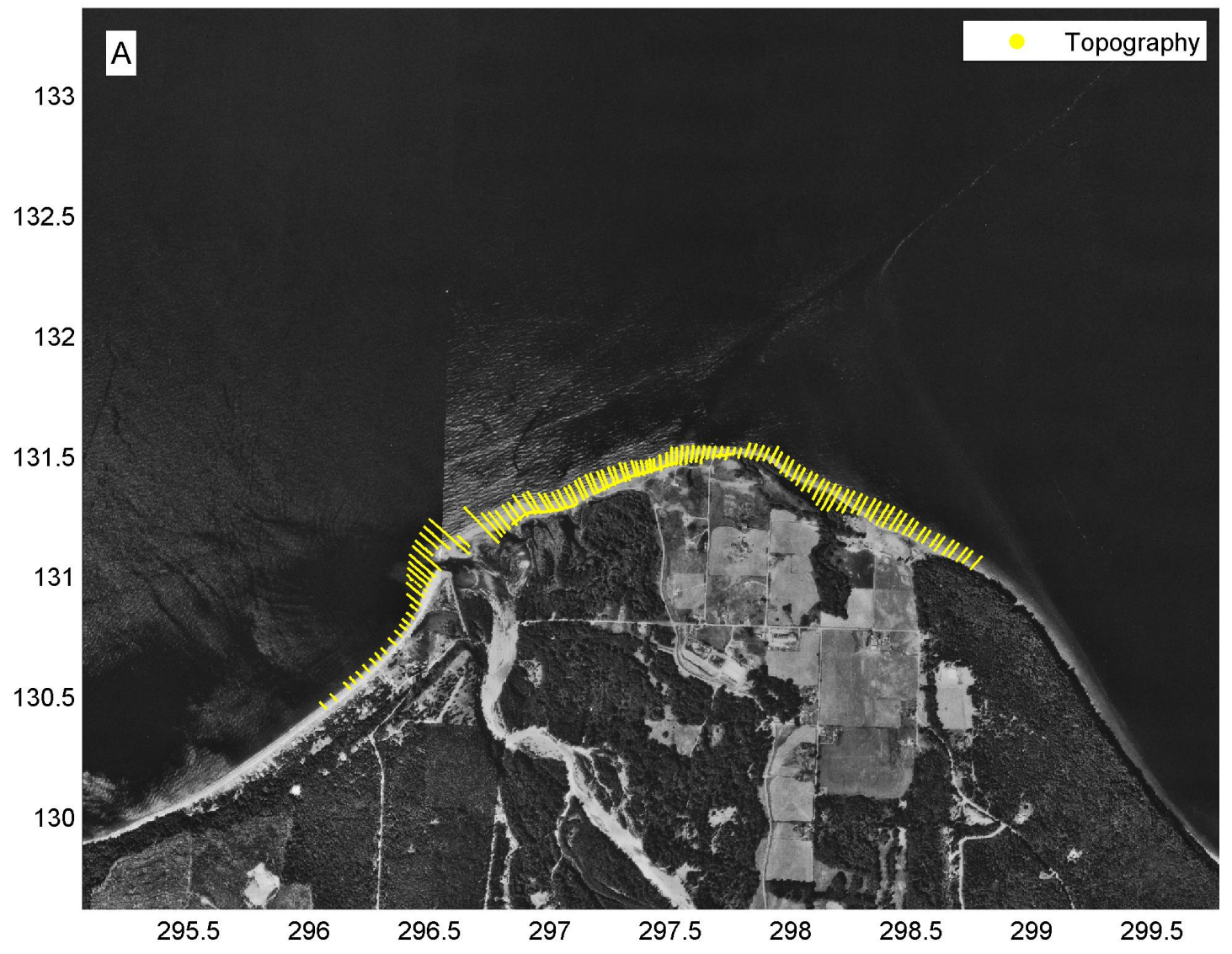

Figure E2. Elwha April 2006 surveyed lines (delta region).

Table E. Topographic lines for the April 2006 survey.

\begin{tabular}{|l|}
\hline Topographic line \\
\hline ew06_line119_t.xyz \\
\hline ew06_line121_t.xyz \\
\hline ew06_line123_t.xyz \\
\hline ew06_line124_t.xyz \\
\hline ew06_line125_t.xyz \\
\hline ew06_line126_t.xyz \\
\hline ew06_line127_t.xyz \\
\hline ew06_line128_t.xyz \\
\hline ew06_line129_t.xyz \\
\hline ew06_line130_t.xyz \\
\hline ew06_line131_t.xyz \\
\hline ew06_line132_t.xyz \\
\hline ew06_line133_t.xyz \\
\hline ew06_line134_t.xyz \\
\hline ew06_line135_t.xyz \\
\hline
\end{tabular}




\begin{tabular}{|c|}
\hline ew06_line136_t.xyz \\
\hline ew06_line137_t.xyz \\
\hline ew06_line138_t.xyz \\
\hline ew06_line139_t.xyz \\
\hline ew06_line140_t.xyz \\
\hline ew06_line141_t.xyz \\
\hline ew06_line142_t.xyz \\
\hline ew06_line143_t.xyz \\
\hline ew06_line144_t.xyz \\
\hline ew06_line145_t.xyz \\
\hline ew06_line146_t.xyz \\
\hline ew06_line147_t.xyz \\
\hline ew06_line150_t.xyz \\
\hline ew06_line151_t.xyz \\
\hline ew06_line152_t.xyz \\
\hline ew06_line153_t.xyz \\
\hline ew06_line154_t.xyz \\
\hline ew06_line155_t.xyz \\
\hline ew06_line156_t.xyz \\
\hline ew06_line157_t.xyz \\
\hline ew06_line158_t.xyz \\
\hline ew06_line159_t.xyz \\
\hline ew06_line160_t.xyz \\
\hline ew06_line161_t.xyz \\
\hline ew06_line162_t.xyz \\
\hline ew06_line163_t.xyz \\
\hline ew06_line164_t.xyz \\
\hline ew06_line165_t.xyz \\
\hline ew06_line166_t.xyz \\
\hline ew06_line167_t.xyz \\
\hline ew06_line168_t.xyz \\
\hline ew06_line169_t.xyz \\
\hline ew06_line170_t.xyz \\
\hline ew06_line171_t.xyz \\
\hline ew06_line172_t.xyz \\
\hline ew06_line173_t.xyz \\
\hline ew06_line174_t.xyz \\
\hline ew06_line175_t.xyz \\
\hline ew06_line176_t.xyz \\
\hline ew06_line177_t.xyz \\
\hline ew06_line178_t.xyz \\
\hline ew06_line179_t.xyz \\
\hline ew06_line180_t.xyz \\
\hline ew06_line181_t.xyz \\
\hline ew06_line182_t.xyz \\
\hline ew06_line183_t.xyz \\
\hline ew06_line184_t.xyz \\
\hline ew06_line185_t.xyz \\
\hline ew06_line186_t.xyz \\
\hline ew06_line187_t.xyz \\
\hline ew06_line188_t.xyz \\
\hline ew06_line189_t.xyz \\
\hline ew06_line190_t.xyz \\
\hline ew06_line191_t.xyz \\
\hline ew06_line192_t.xyz \\
\hline
\end{tabular}




\begin{tabular}{|l|}
\hline ew06_line193_t.xyz \\
\hline ew06_line194_t.xyz \\
\hline ew06_line195_t.xyz \\
\hline ew06_line196_t.xyz \\
\hline ew06_line197_t.xyz \\
\hline ew06_line198_t.xyz \\
\hline ew06_line199_t.xyz \\
\hline ew06_line200_t.xyz \\
\hline ew06_line201_t.xyz \\
\hline ew06_line202_t.xyz \\
\hline ew06_line203_t.xyz \\
\hline ew06_line204_t.xyz \\
\hline ew06_line205_t.xyz \\
\hline ew06_line206_t.xyz \\
\hline ew06_line207_t.xyz \\
\hline ew06_line208_t.xyz \\
\hline ew06_line209_t.xyz \\
\hline ew06_line210_t.xyz \\
\hline ew06_line211_t.xyz \\
\hline ew06_line212_t.xyz \\
\hline ew06_line213_t.xyz \\
\hline ew06_line214_t.xyz \\
\hline ew06_line215_t.xyz \\
\hline ew06_line216_t.xyz \\
\hline ew06_line217_t.xyz \\
\hline ew06_line218_t.xyz \\
\hline ew06_line219_t.xyz \\
\hline ew06_line220_t.xyz \\
\hline ew06_line221_t.xyz \\
\hline ew06_line222_t.xyz \\
\hline ew06_line223_t.xyz \\
\hline ew06_line224_t.xyz \\
\hline ew06_line225_t.xyz \\
\hline ew06_line226_t.xyz \\
\hline ew06_line227_t.xyz \\
\hline ew06_line228_t.xyz \\
\hline ew06_line229_t.xyz \\
\hline ew06_line230_t.xyz \\
\hline ew06_line231_t.xyz \\
\hline ew06_line232_t.xyz \\
\hline
\end{tabular}




\section{Appendix F - September 2006 Field Collection}

In September 2006, the area around the delta was heavily sampled. On September 18-19, 103 bathymetric profiles and 153 topographic profiles were collected between line numbers 80 to the west and 240 to the east (figs. F1-F2). Additionally, data were collected within the river mouth by driving the PWCs through the river mouth and traversing from one side of the river to the other. Bathymetric and topographic lines collected during this survey (USGS Field Activity W-5-06-PS) are enumerated in table F. Metadata for this activity are available at: http://walrus.wr.usgs.gov/infobank/w/w506ps/html/w-5-06ps.meta.html.

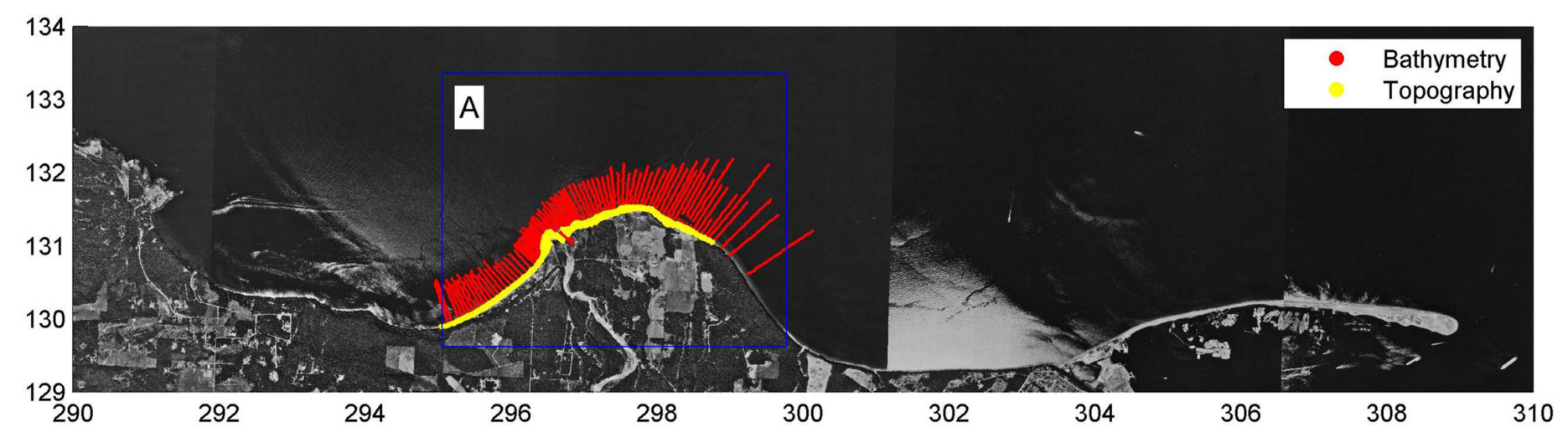

Figure F1. Elwha September 2006 surveyed lines. 


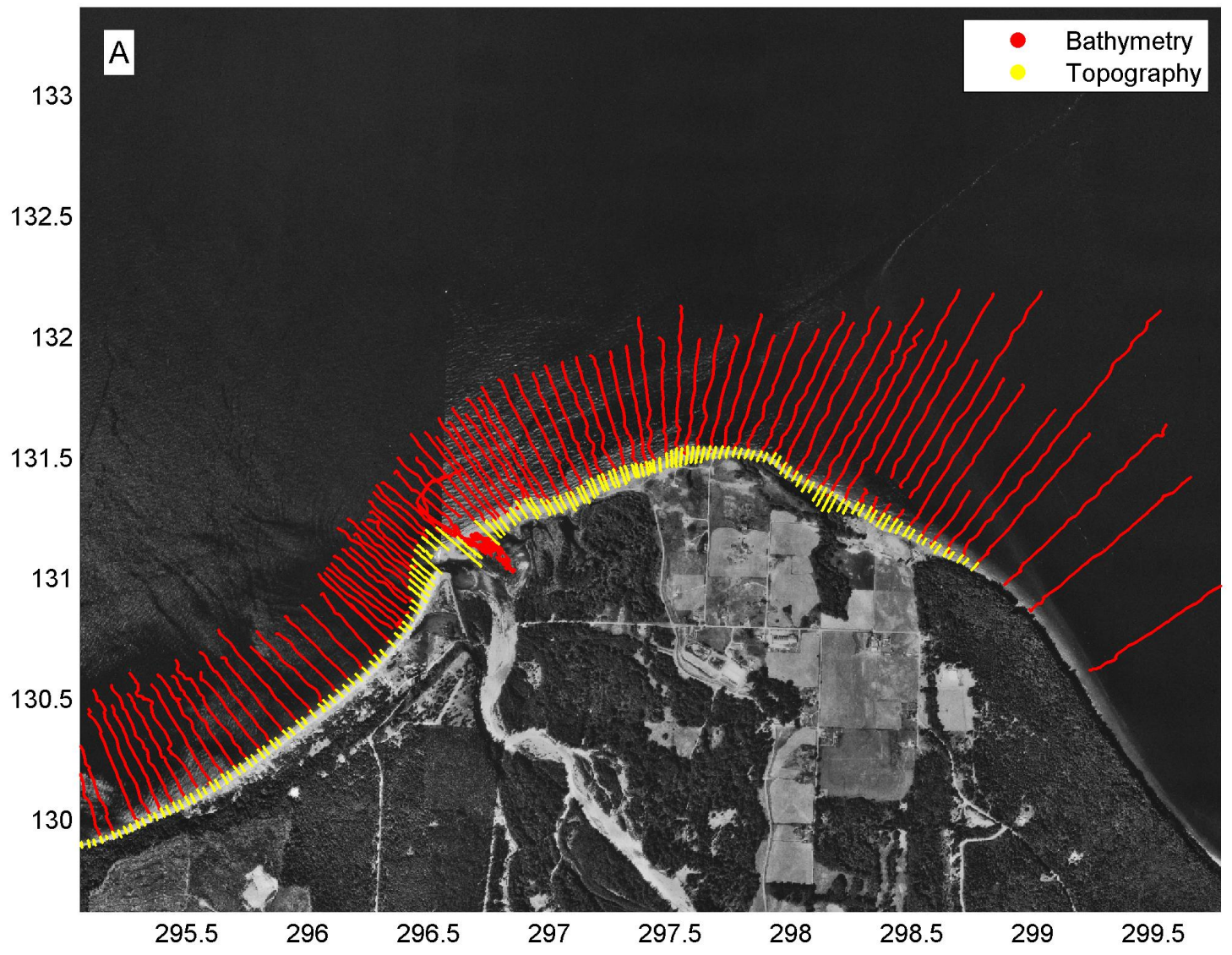

Figure F2. Elwha September 2006 surveyed lines (delta region).

Table F. Bathymetric and topographic lines for the September 2006 survey.

\begin{tabular}{|c|c|}
\hline Bathymetric line & Topographic line \\
\hline & ew06_line080_t.xyz \\
\hline & ew06_line081_t.xyz \\
\hline & ew06_line082_t.xyz \\
\hline & ew06_line083_t.xyz \\
\hline ew06_line084_b.xyz & ew06_line084_t.xyz \\
\hline & ew06_line085_t.xyz \\
\hline ew06_line086_b.xyz & ew06_line086_t.xyz \\
\hline & ew06_line087_t.xyz \\
\hline & ew06_line088_t.xyz \\
\hline & ew06_line089_t.xyz \\
\hline ew06_line090_b.xyz & ew06_line090_t.xyz \\
\hline & ew06_line091_t.xyz \\
\hline ew06_line092_b.xyz & ew06_line092_t.xyz \\
\hline & ew06_line093_t.xyz \\
\hline ew06_line094_b.xyz & ew06_line094_t.xyz \\
\hline
\end{tabular}




\begin{tabular}{|c|c|}
\hline & ew06_line095_t.xyz \\
\hline \multirow[t]{2}{*}{ ew06_line096_b.xyz } & ew06_line096_t.xyz \\
\hline & ew06_line097_t.xyz \\
\hline \multirow[t]{2}{*}{ ew06_line098_b.xyz } & ew06_line098_t.xyz \\
\hline & ew06_line099_t.xyz \\
\hline \multirow[t]{2}{*}{ ew06_line100_b.xyz } & ew06_line100_t.xyz \\
\hline & ew06_line101_t.xyz \\
\hline \multirow[t]{2}{*}{ ew06_line102_b.xyz } & ew06_line102_t.xyz \\
\hline & ew06_line103_t.xyz \\
\hline \multirow[t]{2}{*}{ ew06_line104_b.xyz } & ew06_line104_t.xyz \\
\hline & ew06_line105_t.xyz \\
\hline \multirow[t]{2}{*}{ ew06_line106_b.xyz } & ew06_line106_t.xyz \\
\hline & ew06_line107_t.xyz \\
\hline \multirow[t]{2}{*}{ ew06_line108_b.xyz } & ew06_line108_t.xyz \\
\hline & ew06_line109_t.xyz \\
\hline \multirow[t]{2}{*}{ ew06_line110_b.xyz } & ew06_line110_t.xyz \\
\hline & ew06_line111_t.xyz \\
\hline \multirow[t]{2}{*}{ ew06_line112_b.xyz } & ew06_line112_t.xyz \\
\hline & ew06_line113_t.xyz \\
\hline \multirow[t]{2}{*}{ ew06_line114_b.xyz } & ew06_line114_t.xyz \\
\hline & ew06_line115_t.xyz \\
\hline \multirow[t]{2}{*}{ ew06_line116_b.xyz } & ew06_line116_t.xyz \\
\hline & ew06_line117_t.xyz \\
\hline \multirow[t]{2}{*}{ ew06_line118_b.xyz } & ew06_line118_t.xyz \\
\hline & ew06_line119_t.xyz \\
\hline \multirow[t]{2}{*}{ ew06_line120_b.xyz } & ew06_line120_t.xyz \\
\hline & ew06_line121_t.xyz \\
\hline \multirow[t]{2}{*}{ ew06_line122_b.xyz } & ew06_line122_t.xyz \\
\hline & ew06_line123_t.xyz \\
\hline \multirow[t]{2}{*}{ ew06_line124_b.xyz } & ew06_line124_t.xyz \\
\hline & ew06_line125_t.xyz \\
\hline \multirow[t]{2}{*}{ ew06_line126_b.xyz } & ew06_line126_t.xyz \\
\hline & ew06_line127_t.xyz \\
\hline \multirow[t]{2}{*}{ ew06_line128_b.xyz } & ew06_line128_t.xyz \\
\hline & ew06_line129_t.xyz \\
\hline ew06_line130_b.xyz & ew06_line130_t.xyz \\
\hline \multicolumn{2}{|l|}{ ew06_line130_b2.xyz } \\
\hline ew06_line131_b.xyz & ew06_line131_t.xyz \\
\hline ew06_line132_b.xyz & ew06_line132_t.xyz \\
\hline ew06_line133_b.xyz & ew06_line133_t.xyz \\
\hline ew06_line134_b.xyz & ew06_line134_t.xyz \\
\hline ew06_line135_b.xyz & ew06_line135_t.xyz \\
\hline ew06_line136_b.xyz & ew06_line136_t.xyz \\
\hline ew06_line137_b.xyz & ew06_line137_t.xyz \\
\hline ew06_line138_b.xyz & ew06_line138_t.xyz \\
\hline ew06_line139_b.xyz & ew06_line139_t.xyz \\
\hline ew06_line140_b.xyz & ew06_line140_t.xyz \\
\hline ew06_line141_b.xyz & ew06_line141_t.xyz \\
\hline ew06_line142_b.xyz & ew06_line142_t.xyz \\
\hline ew06_line143_b.xyz & ew06_line143_t.xyz \\
\hline ew06_line144_b.xyz & ew06_line144_t.xyz \\
\hline ew06_line145_b.xyz & ew06_line145_t.xyz \\
\hline ew06_line146_b.xyz & ew06_line146_t.xyz \\
\hline ew06_line147_b.xyz & ew06_line147_t.xyz \\
\hline
\end{tabular}




\begin{tabular}{|c|c|}
\hline ew06_line147_b2.xyz & \\
\hline \multicolumn{2}{|l|}{ ew06_line147_b3.xyz } \\
\hline ew06_line148_b.xyz & ew06_line148_t.xyz \\
\hline ew06_line149_b.xyz & ew06_line149_t.xyz \\
\hline ew06_line150_b.xyz & ew06_line150_t.xyz \\
\hline ew06_line151_b.xyz & ew06_line151_t.xyz \\
\hline ew06_line152_b.xyz & ew06_line152_t.xyz \\
\hline ew06_line153_b.xyz & ew06_line153_t.xyz \\
\hline ew06_line154_b.xyz & ew06_line154_t.xyz \\
\hline ew06_line155_b.xyz & ew06_line155_t.xyz \\
\hline ew06_line156_b.xyz & ew06_line156_t.xyz \\
\hline ew06_line157_b.xyz & ew06_line157_t.xyz \\
\hline ew06_line158_b.xyz & ew06_line158_t.xyz \\
\hline ew06_line159_b.xyz & ew06_line159_t.xyz \\
\hline \multirow[t]{2}{*}{ ew06_line160_b.xyz } & ew06_line160_t.xyz \\
\hline & ew06_line161_t.xyz \\
\hline \multirow[t]{2}{*}{ ew06_line162_b.xyz } & ew06_line162_t.xyz \\
\hline & ew06_line163_t.xyz \\
\hline \multirow[t]{2}{*}{ ew06_line164_b.xyz } & ew06_line164_t.xyz \\
\hline & ew06_line165_t.xyz \\
\hline \multirow[t]{2}{*}{ ew06_line166_b.xyz } & ew06_line166_t.xyz \\
\hline & ew06_line167_t.xyz \\
\hline \multirow[t]{2}{*}{ ew06_line168_b.xyz } & ew06_line168_t.xyz \\
\hline & ew06_line169_t.xyz \\
\hline \multirow[t]{2}{*}{ ew06_line170_b.xyz } & ew06_line170_t.xyz \\
\hline & ew06_line171_t.xyz \\
\hline \multirow[t]{2}{*}{ ew06_line172_b.xyz } & ew06_line172_t.xyz \\
\hline & ew06_line173_t.xyz \\
\hline \multirow{2}{*}{ ew06_line174_b.xyz } & ew06_line174_t.xyz \\
\hline & ew06_line175_t.xyz \\
\hline \multirow[t]{2}{*}{ ew06_line176_b.xyz } & ew06_line176_t.xyz \\
\hline & ew06_line177_t.xyz \\
\hline \multirow[t]{2}{*}{ ew06_line178_b.xyz } & ew06_line178_t.xyz \\
\hline & ew06_line179_t.xyz \\
\hline \multirow[t]{2}{*}{ ew06_line180_b.xyz } & ew06_line180_t.xyz \\
\hline & ew06_line181_t.xyz \\
\hline \multirow[t]{2}{*}{ ew06_line182_b.xyz } & ew06_line182_t.xyz \\
\hline & ew06_line183_t.xyz \\
\hline \multirow[t]{2}{*}{ ew06_line184_b.xyz } & ew06_line184_t.xyz \\
\hline & ew06_line185_t.xyz \\
\hline \multirow[t]{2}{*}{ ew06_line186_b.xyz } & ew06_line186_t.xyz \\
\hline & ew06_line187_t.xyz \\
\hline \multirow[t]{2}{*}{ ew06_line188_b.xyz } & ew06_line188_t.xyz \\
\hline & ew06_line189_t.xyz \\
\hline \multirow[t]{2}{*}{ ew06_line190_b.xyz } & ew06_line190_t.xyz \\
\hline & ew06_line191_t.xyz \\
\hline \multirow[t]{2}{*}{ ew06_line192_b.xyz } & ew06_line192_t.xyz \\
\hline & ew06_line193_t.xyz \\
\hline \multirow[t]{2}{*}{ ew06_line194_b.xyz } & ew06_line194_t.xyz \\
\hline & ew06_line195_t.xyz \\
\hline \multirow[t]{2}{*}{ ew06_line196_b.xyz } & ew06_line196_t.xyz \\
\hline & ew06_line197_t.xyz \\
\hline \multirow[t]{2}{*}{ ew06_line198_b.xyz } & ew06_line198_t.xyz \\
\hline & ew06_line199_t.xyz \\
\hline
\end{tabular}




\begin{tabular}{|c|c|}
\hline ew06_line200_b.xyz & ew06_line200_t.xyz \\
\hline & ew06_line201_t.xyz \\
\hline \multirow[t]{2}{*}{ ew06_line202_b.xyz } & ew06_line202_t.xyz \\
\hline & ew06_line203_t.xyz \\
\hline \multirow[t]{2}{*}{ ew06_line204_b.xyz } & ew06_line204_t.xyz \\
\hline & ew06_line205_t.xyz \\
\hline \multirow[t]{2}{*}{ ew06_line206_b.xyz } & ew06_line206_t.xyz \\
\hline & ew06_line207_t.xyz \\
\hline \multirow[t]{2}{*}{ ew06_line208_b.xyz } & ew06_line208_t.xyz \\
\hline & ew06_line209_t.xyz \\
\hline \multirow[t]{2}{*}{ ew06_line210_b.xyz } & ew06_line210_t.xyz \\
\hline & ew06_line211_t.xyz \\
\hline \multirow[t]{2}{*}{ ew06_line212_b.xyz } & ew06_line212_t.xyz \\
\hline & ew06_line213_t.xyz \\
\hline ew06_line214_b.xyz & ew06_line214_t.xyz \\
\hline \multicolumn{2}{|l|}{ ew06_line214_b2.xyz } \\
\hline & ew06_line215_t.xyz \\
\hline ew06_line216_b.xyz & ew06_line216_t.xyz \\
\hline \multicolumn{2}{|l|}{ ew06_line216_b2.xyz } \\
\hline & ew06_line217_t.xyz \\
\hline ew06_line218_b.xyz & ew06_line218_t.xyz \\
\hline \multicolumn{2}{|l|}{ ew06_line218_b2.xyz } \\
\hline & ew06_line219_t.xyz \\
\hline ew06_line220_b.xyz & ew06_line220_t.xyz \\
\hline \multicolumn{2}{|l|}{ ew06_line220_b2.xyz } \\
\hline & ew06_line221_t.xyz \\
\hline \multirow[t]{2}{*}{ ew06_line222_b.xyz } & ew06_line222_t.xyz \\
\hline & ew06_line223_t.xyz \\
\hline \multirow[t]{2}{*}{ ew06_line224_b.xyz } & ew06_line224_t.xyz \\
\hline & ew06_line225_t.xyz \\
\hline \multirow[t]{2}{*}{ ew06_line226_b.xyz } & ew06_line226_t.xyz \\
\hline & ew06_line227_t.xyz \\
\hline \multirow[t]{2}{*}{ ew06_line228_b.xyz } & ew06_line228_t.xyz \\
\hline & ew06_line229_t.xyz \\
\hline \multirow[t]{2}{*}{ ew06_line230_b.xyz } & ew06_line230_t.xyz \\
\hline & ew06_line231_t.xyz \\
\hline ew06_line232_b.xyz & ew06_line232_t.xyz \\
\hline \multicolumn{2}{|l|}{ ew06_line234_b.xyz } \\
\hline \multicolumn{2}{|l|}{ ew06_line236_b.xyz } \\
\hline ew06_line240_b.xyz & \\
\hline
\end{tabular}




\section{Appendix G - April 2007 Field Collection}

In April 2007, no bathymetric data were collected during this survey due to unsafe weather, as the winds and waves were too large to sample the nearshore by watercraft. Between 18-20 April, 145 topographic profiles were collected between line numbers 92 to the west and 232 to the east (figs. G1G2). Topographic lines collected during the April 2007 survey (USGS Field Activity W-S1-07-PS) are enumerated in table G. Metadata for this field activity are available at: http://walrus.wr.usgs.gov/infobank/w/ws107ps/html/w-s1-07-ps.meta.html.

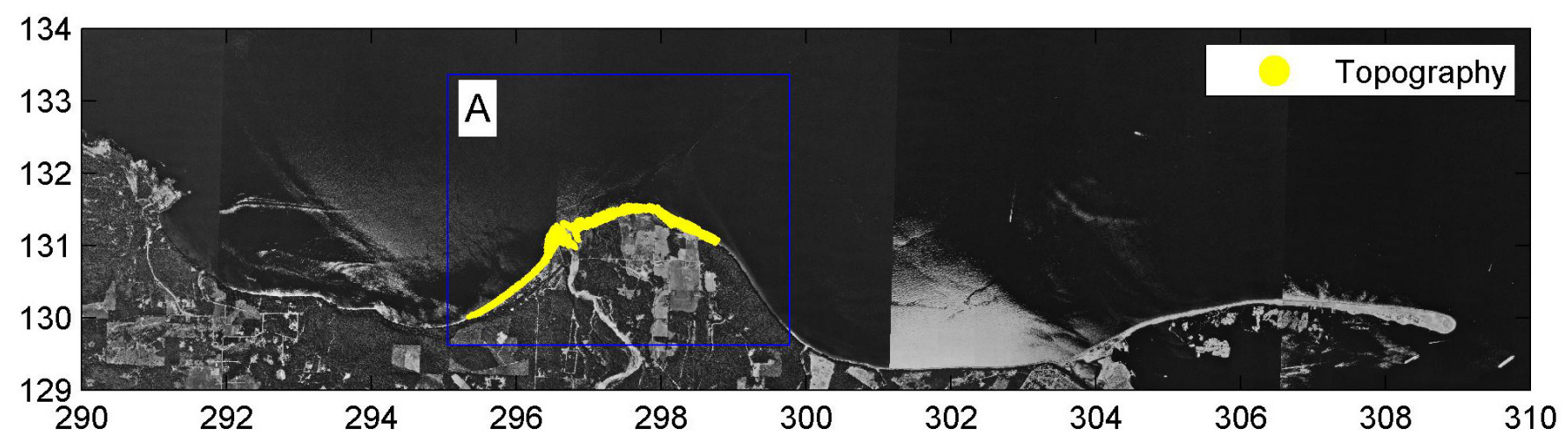

Figure G1. Elwha April 2007 surveyed lines. Only topography data were collected. 


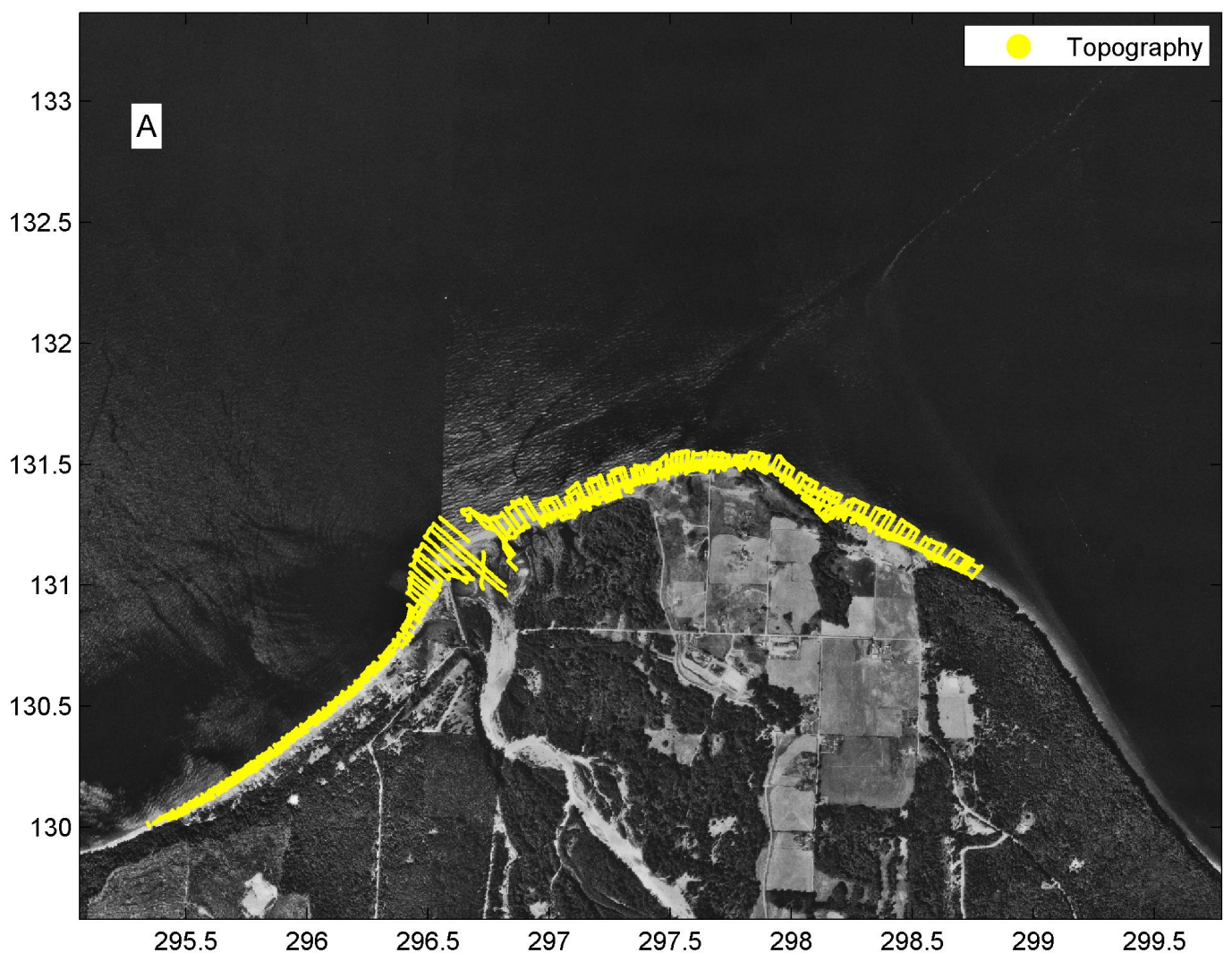

Figure G2. Elwha April 2007 surveyed lines (delta region). Only topography data were collected.

Table G. Topographic lines for the April 2007 survey.

\begin{tabular}{|l|}
\hline Topographic Line \\
\hline ew07_line092_t.xyz \\
\hline ew07_line094_t.xyz \\
\hline ew07_line095_t.xyz \\
\hline ew07_line096_t.xyz \\
\hline ew07_line097_t.xyz \\
\hline ew07_line098_t.xyz \\
\hline ew07_line099_t.xyz \\
\hline ew07_line100_t.xyz \\
\hline ew07_line101_t.xyz \\
\hline ew07_line102_t.xyz \\
\hline ew07_line103_t.xyz \\
\hline ew07_line104_t.xyz \\
\hline ew07_line105_t.xyz \\
\hline ew07_line106_t.xyz \\
\hline ew07_line107_t.xyz \\
\hline
\end{tabular}




\begin{tabular}{|l|}
\hline ew07_line108_t.xyz \\
\hline ew07_line109_t.xyz \\
\hline ew07_line110_t.xyz \\
\hline ew07_line111_t.xyz \\
\hline ew07_line112_t.xyz \\
\hline ew07_line113_t.xyz \\
\hline ew07_line114_t.xyz \\
\hline ew07_line115_t.xyz \\
\hline ew07_line116_t.xyz \\
\hline ew07_line117_t.xyz \\
\hline ew07_line118_t.xyz \\
\hline ew07_line119_t.xyz \\
\hline ew07_line120_t.xyz \\
\hline ew07_line121_t.xyz \\
\hline ew07_line122_t.xyz \\
\hline ew07_line123_t.xyz \\
\hline ew07_line124_t.xyz \\
\hline ew07_line125_t.xyz \\
\hline ew07_line126_t.xyz \\
\hline ew07_line127_t.xyz \\
\hline ew07_line128_t.xyz \\
\hline ew07_line129_t.xyz \\
\hline ew07_line130_t.xyz \\
\hline ew07_line131_t.xyz \\
\hline ew07_line132_t.xyz \\
\hline ew07_line133_t.xyz \\
\hline ew07_line134_t.xyz \\
\hline ew07_line135_t.xyz \\
\hline ew07_line136_t.xyz \\
\hline ew07_line137_t.xyz \\
\hline ew07_line138_t.xyz \\
\hline ew07_line139_t.xyz \\
\hline ew07_line140_t.xyz \\
\hline ew07_line141_t.xyz \\
\hline ew07_line146_t.xyz157txyz \\
\hline ew07_line143_t.xyz \\
\hline ew07_line144_t.xyz \\
\hline ew07_line145_t.xyz \\
\hline ew07_line146_t.xyz \\
\hline ew07_line147_t.xyz \\
\hline ew07_line148_t.xyz \\
\hline
\end{tabular}




\begin{tabular}{|l|}
\hline ew07_line158_t.xyz \\
\hline ew07_line159_t.xyz \\
\hline ew07_line160_t.xyz \\
\hline ew07_line161_t.xyz \\
\hline ew07_line162_t.xyz \\
\hline ew07_line163_t.xyz \\
\hline ew07_line164_t.xyz \\
\hline ew07_line165_t.xyz \\
\hline ew07_line166_t.xyz \\
\hline ew07_line167_t.xyz \\
\hline ew07_line168_t.xyz \\
\hline ew07_line169_t.xyz \\
\hline ew07_line170_t.xyz \\
\hline ew07_line171_t.xyz \\
\hline ew07_line172_t.xyz \\
\hline ew07_line173_t.xyz \\
\hline ew07_line174_t.xyz \\
\hline ew07_line175_t.xyz \\
\hline ew07_line176_t.xyz \\
\hline ew07_line177_t.xyz \\
\hline ew07_line178_t.xyz \\
\hline ew07_line179_t.xyz \\
\hline ew07_line180_t.xyz \\
\hline ew07_line181_t.xyz \\
\hline ew07_line182_t.xyz \\
\hline ew07_line183_t.xyz \\
\hline ew07_line184_t.xyz \\
\hline ew07_line185_t.xyz \\
\hline ew07_line186_t.xyz \\
\hline ew07_line187_t.xyz \\
\hline ew07_line189_t.xyz \\
\hline ew07_line190_t.xyz \\
\hline ew07_line191_t.xyz \\
\hline ew07_line192_t.xyz \\
\hline ew07_line193_t.xyz \\
\hline ew07_line194_t.xyz \\
\hline ew07_line195_t.xyz \\
\hline ew07_line196_t.xyz \\
\hline ew07_line197_t.xyz \\
\hline ew07_line198_t.xyz \\
\hline ew07_line199_t.xyz \\
\hline ew07_line200_t.xyz \\
\hline
\end{tabular}




\begin{tabular}{|l|}
\hline ew07_line207_t.xyz \\
\hline ew07_line208_t.xyz \\
\hline ew07_line209_t.xyz \\
\hline ew07_line210_t.xyz \\
\hline ew07_line211_t.xyz \\
\hline ew07_line212_t.xyz \\
\hline ew07_line213_t.xyz \\
\hline ew07_line214_t.xyz \\
\hline ew07_line215_t.xyz \\
\hline ew07_line216_t.xyz \\
\hline ew07_line217_t.xyz \\
\hline ew07_line218_t.xyz \\
\hline ew07_line219_t.xyz \\
\hline ew07_line220_t.xyz \\
\hline ew07_line221_t.xyz \\
\hline ew07_line222_t.xyz \\
\hline ew07_line223_t.xyz \\
\hline ew07_line224_t.xyz \\
\hline ew07_line225_t.xyz \\
\hline ew07_line226_t.xyz \\
\hline ew07_line227_t.xyz \\
\hline ew07_line228_t.xyz \\
\hline ew07_line229_t.xyz \\
\hline ew07_line230_t.xyz \\
\hline ew07_line231_t.xyz \\
\hline ew07_line232_t.xyz \\
\hline ew07_001grid_t.xyz \\
\hline ew07_002grid_t.xyz \\
\hline ew07_003grid_t.xyz \\
\hline ew07_004grid_t.xyz \\
\hline ew07_005grid_t.xyz \\
\hline ew07_006grid_t.xyz \\
\hline ew07_007grid_t.xyz \\
\hline ew07_008grid_t.xyz \\
\hline
\end{tabular}




\section{Appendix H - September 2007 Field Collection}

In September 2007, data collection focused on the river mouth and adjacent delta. On 6-8

September, 81 bathymetric profiles and 88 topographic profiles between line numbers 126 to the west and 217 to the east (fig. H1-H2). Bathymetric and topographic lines collected during the September 2007 survey (USGS Field Activity W-2-07-PS) are enumerated in table H. Metadata for this field activity are available at: http://walrus.wr.usgs.gov/infobank/w/w207ps/html/w-2-07-ps.meta.html.

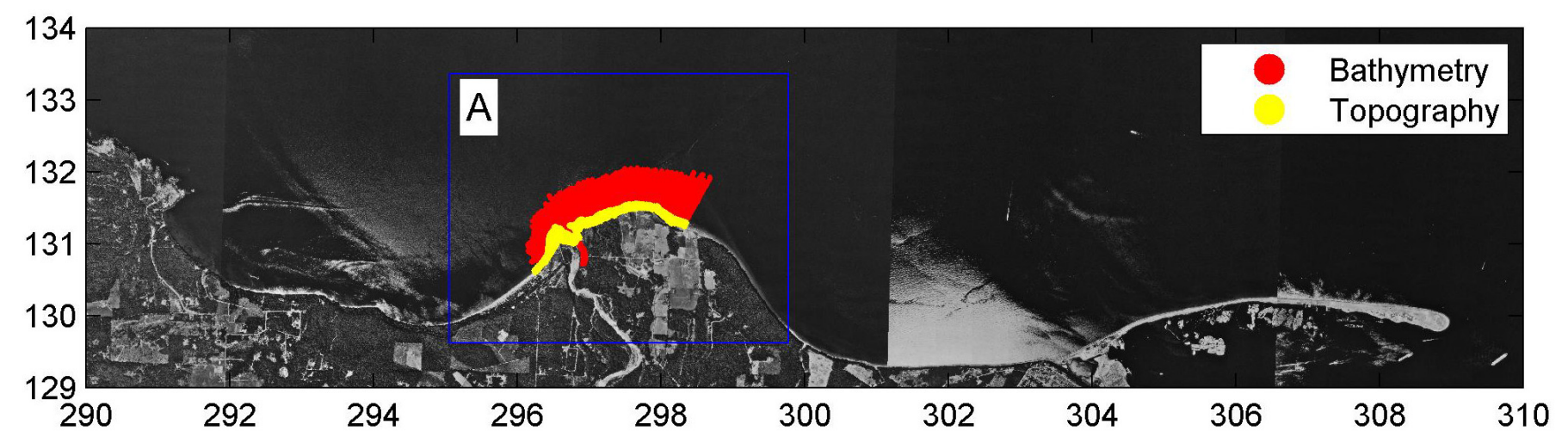

Figure H1. Elwha September 2007 surveyed lines. 


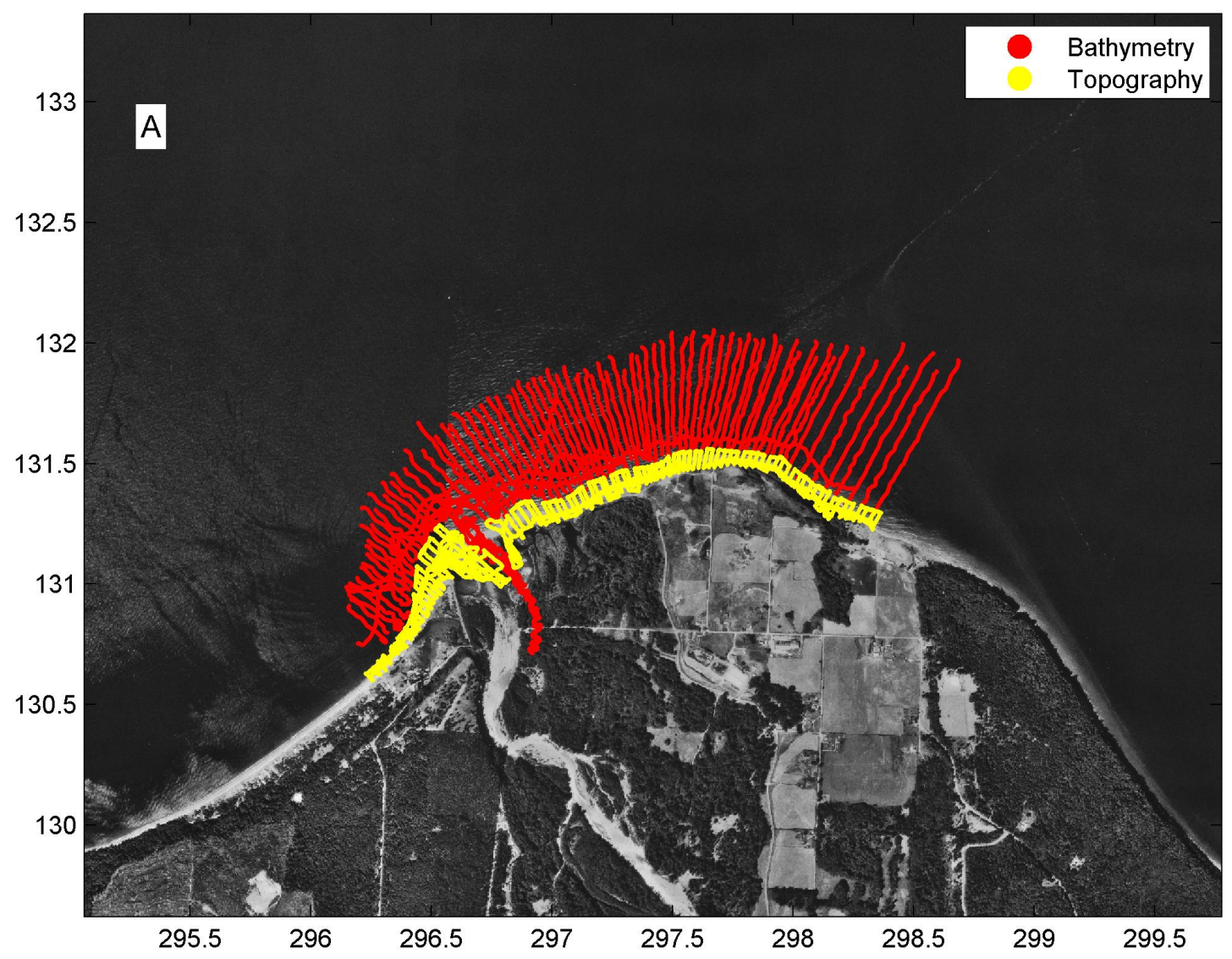

Figure H2. Elwha September 2007 surveyed lines (delta region).

Table H. Bathymetric and topographic lines for the September 2007 survey.

\begin{tabular}{|c|c|}
\hline Bathymetric Line & Topographic Line \\
\hline & ew07_line126_t.xyz \\
\hline & ew07_line127_t.xyz \\
\hline & ew07_line128_t.xyz \\
\hline & ew07_line129_t.xyz \\
\hline ew07_line130_b.xyz & ew07_line130_t.xyz \\
\hline ew07_line131_b.xyz & ew07_line131_t.xyz \\
\hline ew07_line132_b.xyz & ew07_line132_t.xyz \\
\hline ew07_line133_b.xyz & ew07_line133_t.xyz \\
\hline ew07_line134_b.xyz & ew07_line134_t.xyz \\
\hline ew07_line135_b.xyz & ew07_line135_t.xyz \\
\hline ew07_line136_b.xyz & ew07_line136_t.xyz \\
\hline ew07_line137_b.xyz & ew07_line137_t.xyz \\
\hline ew07_line138_b.xyz & ew07_line138_t.xyz \\
\hline
\end{tabular}




\begin{tabular}{|c|c|}
\hline ew07_line139_b.xyz & ew07_line139_t.xyz \\
\hline ew07_line140_b.xyz & ew07_line140_t.xyz \\
\hline ew07_line141_b.xyz & ew07_line141_t.xyz \\
\hline ew07_line142_b.xyz & ew07_line142_t.xyz \\
\hline ew07_line143_b.xyz & ew07_line143_t.xyz \\
\hline ew07_line144_b.xyz & ew07_line144_t.xyz \\
\hline ew07_line145_b.xyz & ew07_line145_t.xyz \\
\hline ew07_line146_b.xyz & ew07_line146_t.xyz \\
\hline ew07_line147_b.xyz & ew07_line147_t.xyz \\
\hline \multicolumn{2}{|l|}{ ew07_line148_b.xyz } \\
\hline \multicolumn{2}{|l|}{ ew07_line149_b.xyz } \\
\hline \multicolumn{2}{|l|}{ ew07_line150_b.xyz } \\
\hline ew07_line151_b.xyz & ew07_line151_t.xyz \\
\hline ew07_line152_b.xyz & ew07_line152_t.xyz \\
\hline ew07_line153_b.xyz & ew07_line153_t.xyz \\
\hline ew07_line154_b.xyz & ew07_line154_t.xyz \\
\hline ew07_line155_b.xyz & ew07_line155_t.xyz \\
\hline ew07_line156_b.xyz & ew07_line156_t.xyz \\
\hline ew07_line157_b.xyz & ew07_line157_t.xyz \\
\hline ew07_line158_b.xyz & ew07_line158_t.xyz \\
\hline ew07_line159_b.xyz & ew07_line159_t.xyz \\
\hline ew07_line160_b.xyz & ew07_line160_t.xyz \\
\hline ew07_line161_b.xyz & ew07_line161_t.xyz \\
\hline ew07_line162_b.xyz & ew07_line162_t.xyz \\
\hline ew07_line163_b.xyz & ew07_line163_t.xyz \\
\hline ew07_line164_b.xyz & ew07_line164_t.xyz \\
\hline ew07_line165_b.xyz & ew07_line165_t.xyz \\
\hline ew07_line166_b.xyz & ew07_line166_t.xyz \\
\hline ew07_line167_b.xyz & ew07_line167_t.xyz \\
\hline ew07_line168_b.xyz & ew07_line168_t.xyz \\
\hline ew07_line169_b.xyz & ew07_line169_t.xyz \\
\hline ew07_line170_b.xyz & ew07_line170_t.xyz \\
\hline ew07_line171_b.xyz & ew07_line171_t.xyz \\
\hline \multicolumn{2}{|l|}{ ew07_line171_b2.xyz } \\
\hline ew07_line172_b.xyz & ew07_line172_t.xyz \\
\hline ew07_line173_b.xyz & ew07_line173_t.xyz \\
\hline ew07_line174_b.xyz & ew07_line174_t.xyz \\
\hline ew07_line175_b.xyz & ew07_line175_t.xyz \\
\hline ew07_line176_b.xyz & ew07_line176_t.xyz \\
\hline \multicolumn{2}{|l|}{ ew07_line177_b.xyz } \\
\hline ew07_line178_b.xyz & ew07_line178_t.xyz \\
\hline ew07_line179_b.xyz & ew07_line179_t.xyz \\
\hline ew07_line180_b.xyz & ew07_line180_t.xyz \\
\hline ew07_line181_b.xyz & ew07_line181_t.xyz \\
\hline ew07_line182_b.xyz & ew07_line182_t.xyz \\
\hline ew07_line183_b.xyz & ew07_line183_t.xyz \\
\hline ew07_line184_b.xyz & ew07_line184_t.xyz \\
\hline ew07_line185_b.xyz & ew07_line185_t.xyz \\
\hline
\end{tabular}




\begin{tabular}{|c|c|}
\hline ew07_line186_b.xyz & ew07_line186_t.xyz \\
\hline ew07_line187_b.xyz & ew07_line187_t.xyz \\
\hline ew07_line188_b.xyz & ew07_line188_t.xyz \\
\hline ew07_line189_b.xyz & ew07_line189_t.xyz \\
\hline ew07_line190_b.xyz & ew07_line190_t.xyz \\
\hline ew07_line191_b.xyz & ew07_line191_t.xyz \\
\hline ew07_line192_b.xyz & ew07_line192_t.xyz \\
\hline ew07_line193_b.xyz & ew07_line193_t.xyz \\
\hline ew07_line194_b.xyz & ew07_line194_t.xyz \\
\hline ew07_line195_b.xyz & ew07_line195_t.xyz \\
\hline ew07_line196_b.xyz & ew07_line196_t.xyz \\
\hline ew07_line197_b.xyz & ew07_line197_t.xyz \\
\hline ew07_line198_b.xyz & ew07_line198_t.xyz \\
\hline ew07_line199_b.xyz & ew07_line199_t.xyz \\
\hline ew07_line200_b.xyz & ew07_line200_t.xyz \\
\hline ew07_line201_b.xyz & ew07_line201_t.xyz \\
\hline \multirow[t]{2}{*}{ ew07_line202_b.xyz } & ew07_line202_t.xyz \\
\hline & ew07_line203_t.xyz \\
\hline \multirow[t]{2}{*}{ ew07_line204_b.xyz } & ew07_line204_t.xyz \\
\hline & ew07_line205_t.xyz \\
\hline \multirow[t]{2}{*}{ ew07_line206_b.xyz } & ew07_line206_t.xyz \\
\hline & ew07_line207_t.xyz \\
\hline \multirow[t]{2}{*}{ ew07_line208_b.xyz } & ew07_line208_t.xyz \\
\hline & ew07_line209_t.xyz \\
\hline \multirow[t]{2}{*}{ ew07_line210_b.xyz } & ew07_line210_t.xyz \\
\hline & ew07_line211_t.xyz \\
\hline \multirow[t]{2}{*}{ ew07_line212_b.xyz } & ew07_line212_t.xyz \\
\hline & ew07_line213_t.xyz \\
\hline \multirow[t]{2}{*}{ ew07_line214_b.xyz } & ew07_line214_t.xyz \\
\hline & ew07_line215_t.xyz \\
\hline \multirow[t]{2}{*}{ ew07_line216_b.xyz } & ew07_line216_t.xyz \\
\hline & ew07_line217_t.xyz \\
\hline ew07_001grid_b.xyz & ew07_001grid_t.xyz \\
\hline ew07_002grid_b.xyz & ew07_002grid_t.xyz \\
\hline ew07_003grid_b.xyz & ew07_003grid_t.xyz \\
\hline ew07_004grid_b.xyz & ew07_004grid_t.xyz \\
\hline \multicolumn{2}{|l|}{ ew07_005grid_b.xyz } \\
\hline \multicolumn{2}{|l|}{ ew07_006grid_b.xyz } \\
\hline \multicolumn{2}{|l|}{ ew07_007grid_b.xyz } \\
\hline \multicolumn{2}{|l|}{ ew07_008grid_b.xyz } \\
\hline \multicolumn{2}{|l|}{ ew07_009grid_b.xyz } \\
\hline \multicolumn{2}{|l|}{ ew07_010grid_b.xyz } \\
\hline ew07_011grid_b.xyz & \\
\hline
\end{tabular}




\section{Appendix I - August 2008 Field Collection}

Between 27 and 29 August, 133 bathymetric profiles and 101 topographic profiles between line numbers 130 to the west and 232 to the east (fig. I1-I2). Bathymetric and topographic lines collected during the survey (USGS Field Activity W-2-08-PS) are enumerated in table I. Metadata for this field activity are available at: http://walrus.wr.usgs.gov/infobank/w/w208ps/html/w-2-08-ps.meta.html.

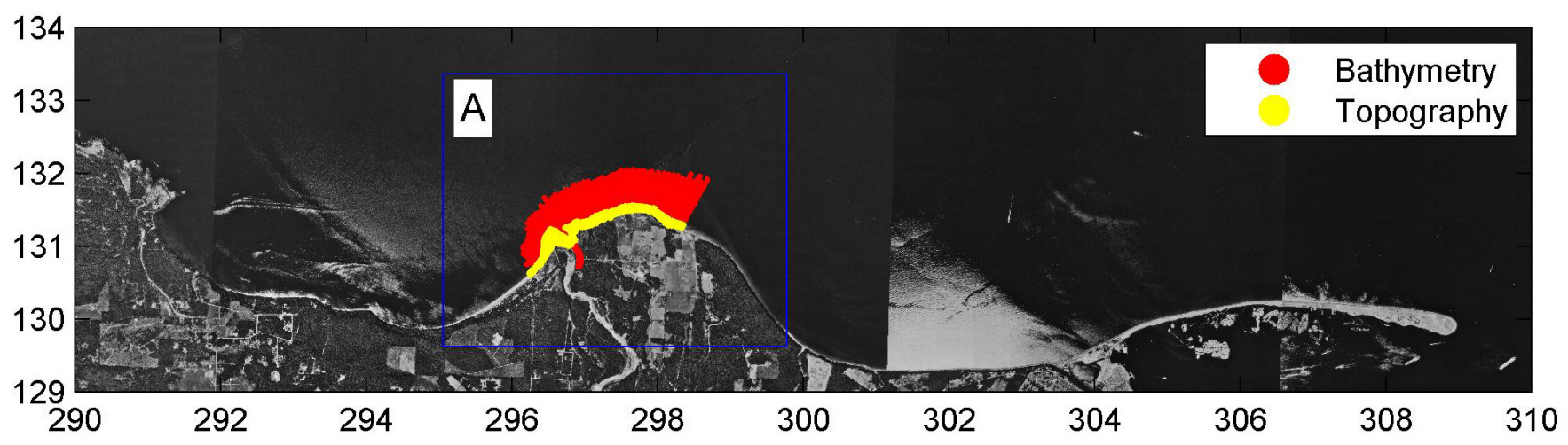

Figure 11. Elwha August 2008 surveyed lines. 


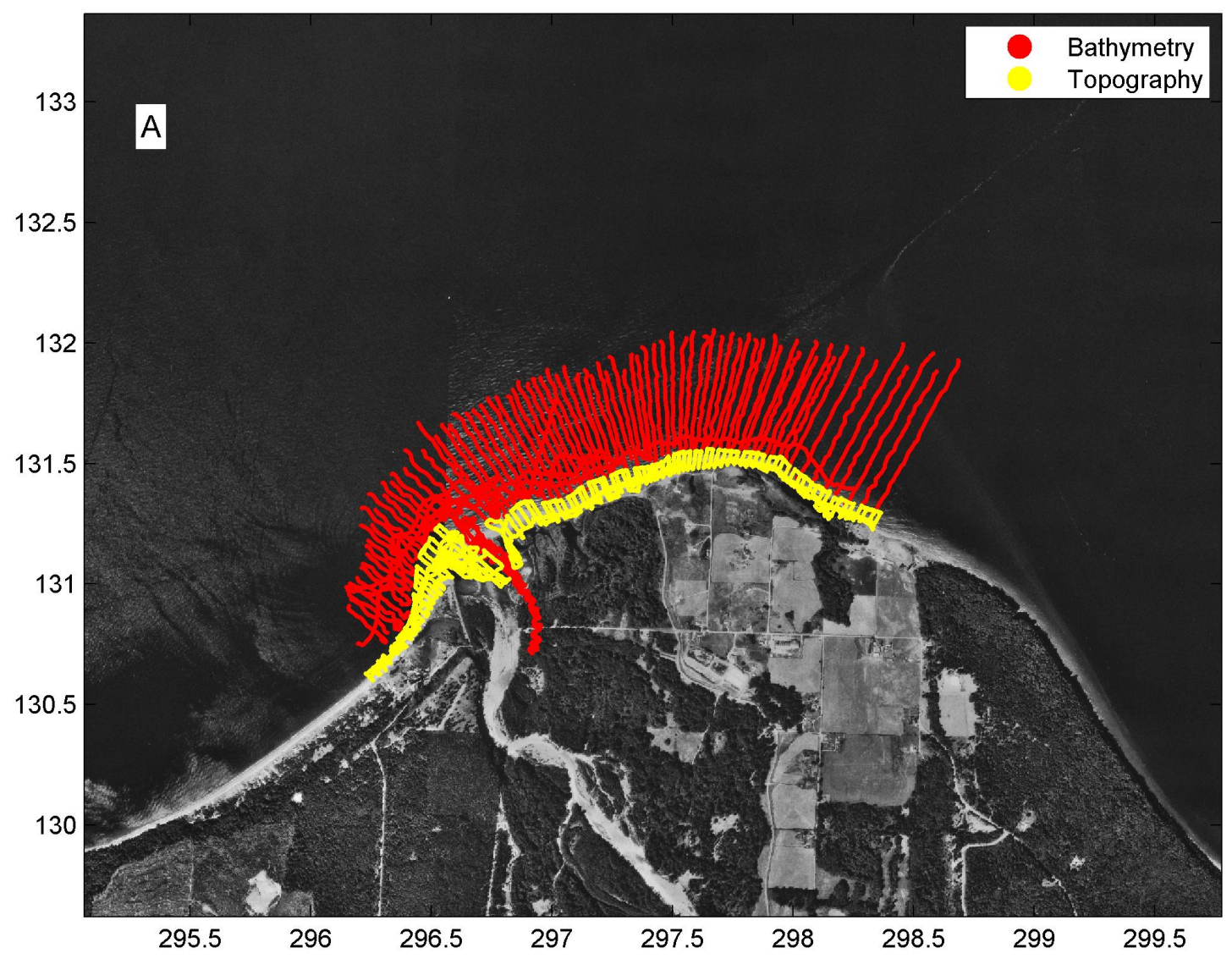

Figure 12. Elwha August 2008 surveyed lines (delta region).

Table I. Bathymetric and topographic lines for the August 2008 survey.

\begin{tabular}{|c|c|}
\hline Bathymetric Line & Topographic Line \\
\hline ew08_line130_b.xyz & ew08_line130_t.xyz \\
\hline ew08_line130_b2.xyz & ew08_line131_t.xyz \\
\hline ew08_line131_b.xyz & ew08_line132_t.xyz \\
\hline ew08_line132_b.xyz & ew08_line133_t.xyz \\
\hline ew08_line133_b.xyz & ew08_line134_t.xyz \\
\hline ew08_line134_b.xyz & ew08_line135_t.xyz \\
\hline ew08_line135_b.xyz & ew08_line136_t.xyz \\
\hline ew08_line136_b.xyz & ew08_line137_t.xyz \\
\hline ew08_line137_b.xyz & ew08_line138_t.xyz \\
\hline ew08_line138_b.xyz & ew08_line139_t.xyz \\
\hline ew08_line139_b.xyz & ew08_line140_t.xyz \\
\hline ew08_line140_b.xyz & ew08_line141_t.xyz \\
\hline ew08_line141_b.xyz &
\end{tabular}




\begin{tabular}{|c|c|}
\hline ew08_line142_b.xyz & ew08_line142_t.xyz \\
\hline ew08_line143_b.xyz & ew08_line143_t.xyz \\
\hline ew08_line144_b.xyz & ew08_line144_t.xyz \\
\hline ew08_line145_b.xyz & ew08_line145_t.xyz \\
\hline ew08_line146_b.xyz & ew08_line146_t.xyz \\
\hline ew08_line147_b.xyz & ew08_line147_t.xyz \\
\hline ew08_line148_b.xyz & \\
\hline ew08_line149_b.xyz & \\
\hline ew08_line150_b.xyz & \\
\hline ew08_line151_b.xyz & \\
\hline ew08_line152_b.xyz & \\
\hline ew08_line153_b.xyz & ew08_line153_t.xyz \\
\hline & ew08_line153_t2.xyz \\
\hline ew08_line154_b.xyz & ew08_line154_t.xyz \\
\hline ew08_line155_b.xyz & ew08_line155_t.xyz \\
\hline ew08_line156_b.xyz & ew08_line156_t.xyz \\
\hline ew08_line157_b.xyz & ew08_line157_t.xyz \\
\hline ew08_line158_b.xyz & ew08_line158_t.xyz \\
\hline ew08_line159_b.xyz & ew08_line159_t.xyz \\
\hline ew08_line160_b.xyz & ew08_line160_t.xyz \\
\hline ew08_line161_b.xyz & ew08_line161_t.xyz \\
\hline ew08_line162_b.xyz & ew08_line162_t.xyz \\
\hline ew08_line163_b.xyz & ew08_line163_t.xyz \\
\hline ew08_line164_b.xyz & ew08_line164_t.xyz \\
\hline ew08_line165_b.xyz & ew08_line165_t.xyz \\
\hline ew08_line166_b.xyz & ew08_line166_t.xyz \\
\hline ew08_line167_b.xyz & ew08_line167_t.xyz \\
\hline & ew08_line168_t.xyz \\
\hline ew08_line169_b.xyz & ew08_line169_t.xyz \\
\hline ew08_line170_b.xyz & ew08_line170_t.xyz \\
\hline ew08_line171_b.xyz & ew08_line171_t.xyz \\
\hline ew08_line172_b.xyz & ew08_line172_t.xyz \\
\hline ew08_line173_b.xyz & ew08_line173_t.xyz \\
\hline ew08_line174_b.xyz & ew08_line174_t.xyz \\
\hline ew08_line175_b.xyz & ew08_line175_t.xyz \\
\hline ew08_line175_b2.xyz & \\
\hline ew08_line176_b.xyz & ew08_line176_t.xyz \\
\hline ew08_line177_b.xyz & ew08_line177_t.xyz \\
\hline ew08_line178_b.xyz & ew08_line178_t.xyz \\
\hline ew08_line179_b.xyz & ew08_line179_t.xyz \\
\hline ew08_line180_b.xyz & ew08_line180_t.xyz \\
\hline ew08_line181_b.xyz & ew08_line181_t.xyz \\
\hline ew08_line182_b.xyz & ew08_line182_t.xyz \\
\hline ew08_line183_b.xyz & ew08_line183_t.xyz \\
\hline ew08_line184_b.xyz & ew08_line184_t.xyz \\
\hline ew08_line185_b.xyz & ew08_line185_t.xyz \\
\hline ew08_line186_b.xyz & ew08_line186_t.xyz \\
\hline ew08_line187_b.xyz & \\
\hline
\end{tabular}




\begin{tabular}{|c|c|}
\hline ew08_line188_b.xyz & ew08_line188_t.xyz \\
\hline ew08_line189_b.xyz & \\
\hline ew08_line190_b.xyz & ew08_line190_t.xyz \\
\hline ew08_line191_b.xyz & ew08_line191_t.xyz \\
\hline ew08_line192_b.xyz & ew08_line192_t.xyz \\
\hline ew08_line193_b.xyz & ew08_line193_t.xyz \\
\hline ew08_line194_b.xyz & ew08_line194_t.xyz \\
\hline ew08_line195_b.xyz & ew08_line195_t.xyz \\
\hline ew08_line196_b.xyz & ew08_line196_t.xyz \\
\hline ew08_line197_b.xyz & ew08_line197_t.xyz \\
\hline ew08_line198_b.xyz & ew08_line198_t.xyz \\
\hline ew08_line199_b.xyz & ew08_line199_t.xyz \\
\hline ew08_line200_b.xyz & ew08_line200_t.xyz \\
\hline ew08_line201_b.xyz & ew08_line201_t.xyz \\
\hline ew08_line202_b.xyz & ew08_line202_t.xyz \\
\hline ew08_line203_b.xyz & ew08_line203_t.xyz \\
\hline ew08_line204_b.xyz & ew08_line204_t.xyz \\
\hline ew08_line205_b.xyz & ew08_line205_t.xyz \\
\hline ew08_line206_b.xyz & ew08_line206_t.xyz \\
\hline ew08_line207_b.xyz & ew08_line207_t.xyz \\
\hline ew08_line208_b.xyz & ew08_line208_t.xyz \\
\hline ew08_line209_b.xyz & ew08_line209_t.xyz \\
\hline ew08_line210_b.xyz & ew08_line210_t.xyz \\
\hline ew08_line211_b.xyz & ew08_line211_t.xyz \\
\hline ew08_line212_b.xyz & ew08_line212_t.xyz \\
\hline ew08_line213_b.xyz & ew08_line213_t.xyz \\
\hline ew08_line214_b.xyz & ew08_line214_t.xyz \\
\hline ew08_line215_b.xyz & ew08_line215_t.xyz \\
\hline ew08_line216_b.xyz & ew08_line216_t.xyz \\
\hline ew08_line217_b.xyz & ew08_line217_t.xyz \\
\hline ew08_line218_b.xyz & ew08_line218_t.xyz \\
\hline ew08_line219_b.xyz & ew08_line219_t.xyz \\
\hline ew08_line220_b.xyz & ew08_line220_t.xyz \\
\hline ew08_line221_b.xyz & ew08_line221_t.xyz \\
\hline ew08_line221_b2.xyz & \\
\hline ew08_line222_b.xyz & ew08_line222_t.xyz \\
\hline ew08_line222_b2.xyz & \\
\hline ew08_line223_b.xyz & ew08_line223_t.xyz \\
\hline ew08_line224_b.xyz & ew08_line224_t.xyz \\
\hline ew08_line225_b.xyz & ew08_line225_t.xyz \\
\hline ew08_line226_b.xyz & ew08_line226_t.xyz \\
\hline ew08_line227_b.xyz & ew08_line227_t.xyz \\
\hline ew08_line228_b.xyz & ew08_line228_t.xyz \\
\hline ew08_line229_b.xyz & ew08_line229_t.xyz \\
\hline ew08_line230_b.xyz & ew08_line230_t.xyz \\
\hline ew08_line231_b.xyz & ew08_line231_t.xyz \\
\hline ew08_line232_b.xyz & ew08_line232_t.xyz \\
\hline ew08_001grid_b.xyz & ew08_001grid_t.xyz \\
\hline
\end{tabular}




\begin{tabular}{|l|l|}
\hline ew08_002grid_b.xyz & ew08_002grid_t.xyz \\
\hline ew08_003grid_b.xyz & ew08_003grid_t.xyz \\
\hline ew08_004grid_b.xyz & ew08_004grid_t.xyz \\
\hline ew08_005grid_b.xyz & \\
\hline ew08_006grid_b.xyz & \\
\hline ew08_007grid_b.xyz & \\
\hline ew08_008grid_b.xyz & \\
\hline ew08_009grid_b.xyz & \\
\hline ew08_010grid_b.xyz & \\
\hline ew08_011grid_b.xyz & \\
\hline ew08_012grid_b.xyz & \\
\hline ew08_013grid_b.xyz & \\
\hline ew08_014grid_b.xyz & \\
\hline ew08_015grid_b.xyz & \\
\hline ew08_016grid_b.xyz & \\
\hline ew08_017grid_b.xyz & \\
\hline ew08_018grid_b.xyz & \\
\hline ew08_019grid_b.xyz & \\
\hline ew08_020grid_b.xyz & \\
\hline ew08_021grid_b.xyz & \\
\hline ew08_022grid_b.xyz & \\
\hline ew08_023grid_b.xyz & \\
\hline ew08_024grid_b.xyz & \\
\hline ew08_025grid_b.xyz & \\
\hline ew08_026grid_b.xyz & \\
\hline ew08_027grid_b.xyz & \\
\hline & \\
\hline & \\
\hline & \\
\hline & \\
\hline & \\
\hline & \\
\hline & \\
\hline
\end{tabular}




\section{Appendix J - September 2009 Field Collection}

In September 2009, data collection focused on the river mouth and adjacent delta. On 15-17

September, 186 bathymetric profiles and 148 topographic profiles between line numbers 93 to the west and 234 to the east (fig. J1-J2). Bathymetric and topographic lines collected during the September 2009 survey (USGS Field Activity W-2-09-PS) are enumerated in table J. Metadata for this field activity are available at: http://walrus.wr.usgs.gov/infobank/w/w209ps/html/w-2-09-ps.meta.html.

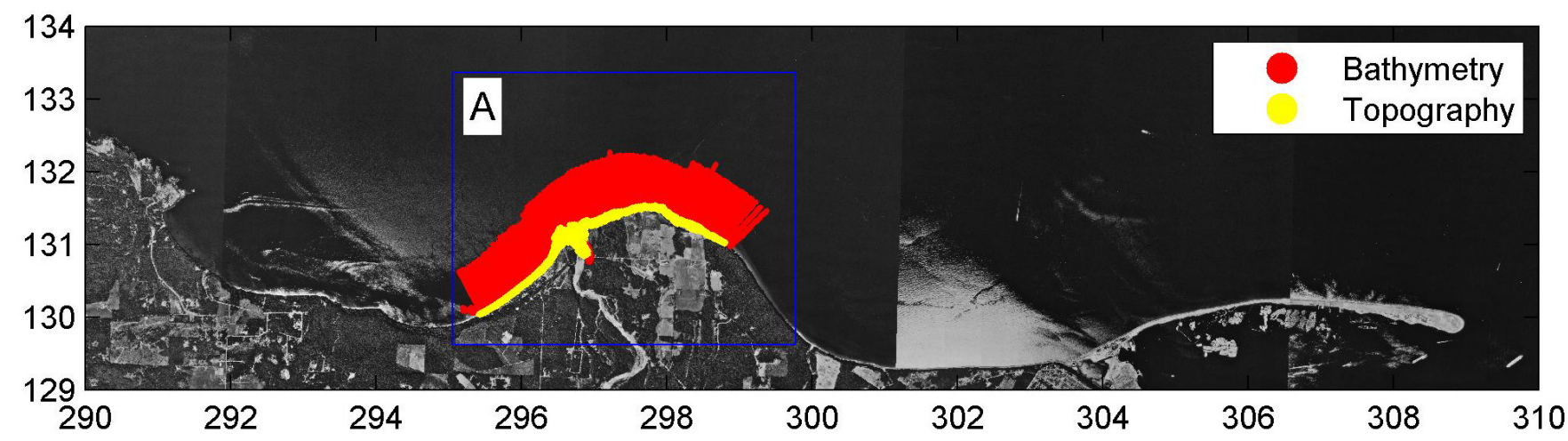

Figure J1. Elwha September 2009 surveyed lines. 


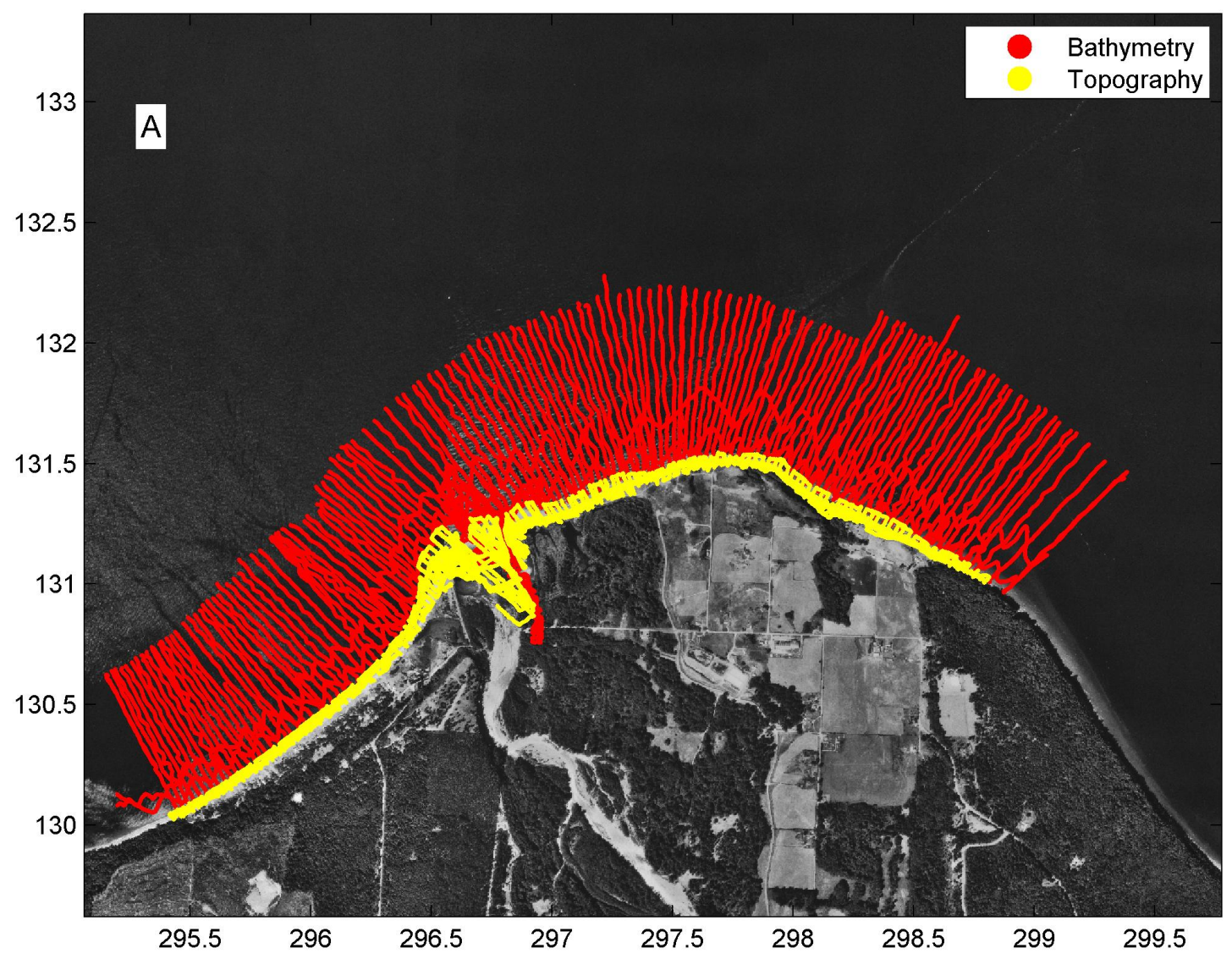

Figure J2. Elwha September 2009 surveyed lines (delta region).

Table J. Bathymetric and topographic lines for the September 2009 survey.

\begin{tabular}{|c|c|}
\hline Bathymetric Line & Topographic Line \\
\hline & ew09_line093_t.xyz \\
\hline & ew09_line095_t.xyz \\
\hline ew09_line096_b.xyz & ew09_line096_t.xyz \\
\hline ew09_line096_b2.xyz & ew09_line097_t.xyz \\
\hline ew09_line097_b.xyz & ew09_line098_t.xyz \\
\hline ew09_line098_b.xyz & ew09_line099_t.xyz \\
\hline ew09_line099_b.xyz & ew09_line100_t.xyz \\
\hline ew09_line100_b.xyz & ew09_line101_t.xyz \\
\hline ew09_line101_b.xyz & ew09_line102_t.xyz \\
\hline ew09_line102_b.xyz & ew09_line103_t.xyz \\
\hline ew09_line103_b.xyz & \\
\hline ew09_line104_b.xyz & ew09_line105_t.xyz \\
\hline ew09_line105_b.xyz &
\end{tabular}




\begin{tabular}{|c|c|}
\hline ew09_line106_b.xyz & ew09_line106_t.xyz \\
\hline ew09_line107_b.xyz & ew09_line107_t.xyz \\
\hline ew09_line108_b.xyz & ew09_line108_t.xyz \\
\hline \multicolumn{2}{|l|}{ ew09_line108_b2.xyz } \\
\hline ew09_line109_b.xyz & ew09_line109_t.xyz \\
\hline ew09_line110_b.xyz & ew09_line110_t.xyz \\
\hline ew09_line111_b.xyz & ew09_line111_t.xyz \\
\hline ew09_line112_b.xyz & ew09_line112_t.xyz \\
\hline ew09_line113_b.xyz & ew09_line113_t.xyz \\
\hline ew09_line114_b.xyz & ew09_line114_t.xyz \\
\hline ew09_line115_b.xyz & ew09_line115_t.xyz \\
\hline ew09_line116_b.xyz & ew09_line116_t.xyz \\
\hline ew09_line117_b.xyz & ew09_line117_t.xyz \\
\hline ew09_line118_b.xyz & ew09_line118_t.xyz \\
\hline ew09_line119_b.xyz & ew09_line119_t.xyz \\
\hline ew09_line120_b.xyz & ew09_line120_t.xyz \\
\hline ew09_line121_b.xyz & ew09_line121_t.xyz \\
\hline ew09_line122_b.xyz & ew09_line122_t.xyz \\
\hline ew09_line123_b.xyz & ew09_line123_t.xyz \\
\hline ew09_line124_b.xyz & ew09_line124_t.xyz \\
\hline ew09_line125_b.xyz & ew09_line125_t.xyz \\
\hline ew09_line126_b.xyz & ew09_line126_t.xyz \\
\hline ew09_line127_b.xyz & ew09_line127_t.xyz \\
\hline ew09_line128_b.xyz & ew09_line128_t.xyz \\
\hline ew09_line129_b.xyz & ew09_line129_t.xyz \\
\hline ew09_line130_b.xyz & ew09_line130_t.xyz \\
\hline ew09_line131_b.xyz & ew09_line131_t.xyz \\
\hline ew09_line132_b.xyz & ew09_line132_t.xyz \\
\hline ew09_line133_b.xyz & ew09_line133_t.xyz \\
\hline \multicolumn{2}{|l|}{ ew09_line133_b2.xyz } \\
\hline ew09_line134_b.xyz & ew09_line134_t.xyz \\
\hline ew09_line135_b.xyz & ew09_line135_t.xyz \\
\hline ew09_line136_b.xyz & ew09_line136_t.xyz \\
\hline ew09_line137_b.xyz & ew09_line137_t.xyz \\
\hline ew09_line138_b.xyz & ew09_line138_t.xyz \\
\hline ew09_line139_b.xyz & ew09_line139_t.xyz \\
\hline ew09_line140_b.xyz & ew09_line140_t.xyz \\
\hline ew09_line141_b.xyz & ew09_line141_t.xyz \\
\hline ew09_line142_b.xyz & ew09_line142_t.xyz \\
\hline ew09_line143_b.xyz & ew09_line143_t.xyz \\
\hline ew09_line144_b.xyz & ew09_line144_t.xyz \\
\hline ew09_line145_b.xyz & ew09_line145_t.xyz \\
\hline ew09_line146_b.xyz & ew09_line146_t.xyz \\
\hline ew09_line147_b.xyz & ew09_line147_t.xyz \\
\hline ew09_line148_b.xyz & ew09_line148_t.xyz \\
\hline ew09_line149_b.xyz & ew09_line149_t.xyz \\
\hline ew09_line150_b.xyz & ew09_line150_t.xyz \\
\hline ew09_line151_b.xyz & ew09_line151_t.xyz \\
\hline
\end{tabular}




\begin{tabular}{|c|c|}
\hline ew09_line152_b.xyz & ew09_line152_t.xyz \\
\hline \multirow[t]{2}{*}{ ew09_line153_b.xyz } & ew09_line153_t.xyz \\
\hline & ew09_line153_t2.xyz \\
\hline ew09_line154_b.xyz & ew09_line154_t.xyz \\
\hline ew09_line154_b2.xyz & ew09_line154_t2.xyz \\
\hline \multirow[t]{2}{*}{ ew09_line155_b.xyz } & ew09_line155_t.xyz \\
\hline & ew09_line155_t2.xyz \\
\hline \multirow[t]{2}{*}{ ew09_line156_b.xyz } & ew09_line156_t.xyz \\
\hline & ew09_line156_t2.xyz \\
\hline \multirow[t]{2}{*}{ ew09_line157_b.xyz } & ew09_line157_t.xyz \\
\hline & ew09_line157_t2.xyz \\
\hline \multirow[t]{2}{*}{ ew09_line158_b.xyz } & ew09_line158_t.xyz \\
\hline & ew09_line158_t2.xyz \\
\hline ew09_line159_b.xyz & ew09_line159_t.xyz \\
\hline ew09_line160_b.xyz & ew09_line160_t.xyz \\
\hline \multicolumn{2}{|l|}{ ew09_line160_b2.xyz } \\
\hline ew09_line161_b.xyz & ew09_line161_t.xyz \\
\hline ew09_line162_b.xyz & ew09_line162_t.xyz \\
\hline ew09_line163_b.xyz & ew09_line163_t.xyz \\
\hline ew09_line164_b.xyz & ew09_line164_t.xyz \\
\hline ew09_line165_b.xyz & ew09_line165_t.xyz \\
\hline ew09_line166_b.xyz & ew09_line166_t.xyz \\
\hline ew09_line167_b.xyz & ew09_line167_t.xyz \\
\hline ew09_line168_b.xyz & ew09_line168_t.xyz \\
\hline ew09_line169_b.xyz & ew09_line169_t.xyz \\
\hline ew09_line170_b.xyz & ew09_line170_t.xyz \\
\hline ew09_line171_b.xyz & ew09_line171_t.xyz \\
\hline ew09_line172_b.xyz & ew09_line172_t.xyz \\
\hline ew09_line173_b.xyz & ew09_line173_t.xyz \\
\hline ew09_line174_b.xyz & ew09_line174_t.xyz \\
\hline ew09_line175_b.xyz & ew09_line175_t.xyz \\
\hline \multicolumn{2}{|l|}{ ew09_line176_b.xyz } \\
\hline ew09_line177_b.xyz & ew09_line177_t.xyz \\
\hline ew09_line178_b.xyz & ew09_line178_t.xyz \\
\hline ew09_line179_b.xyz & ew09_line179_t.xyz \\
\hline ew09_line180_b.xyz & ew09_line180_t.xyz \\
\hline ew09_line181_b.xyz & ew09_line181_t.xyz \\
\hline ew09_line182_b.xyz & ew09_line182_t.xyz \\
\hline ew09_line183_b.xyz & ew09_line183_t.xyz \\
\hline ew09_line184_b.xyz & ew09_line184_t.xyz \\
\hline \multicolumn{2}{|l|}{ ew09_line184_b2.xyz } \\
\hline \multicolumn{2}{|l|}{ ew09_line184_b3.xyz } \\
\hline ew09_line185_b.xyz & ew09_line185_t.xyz \\
\hline ew09_line186_b.xyz & ew09_line186_t.xyz \\
\hline ew09_line187_b.xyz & ew09_line187_t.xyz \\
\hline ew09_line188_b.xyz & ew09_line188_t.xyz \\
\hline ew09_line189_b.xyz & ew09_line189_t.xyz \\
\hline ew09_line190_b.xyz & ew09_line190_t.xyz \\
\hline
\end{tabular}




\begin{tabular}{|c|c|}
\hline ew09_line191_b.xyz & ew09_line191_t.xyz \\
\hline ew09_line192_b.xyz & ew09_line192_t.xyz \\
\hline ew09_line193_b.xyz & ew09_line193_t.xyz \\
\hline ew09_line194_b.xyz & ew09_line194_t.xyz \\
\hline ew09_line195_b.xyz & ew09_line195_t.xyz \\
\hline ew09_line196_b.xyz & ew09_line196_t.xyz \\
\hline ew09_line197_b.xyz & ew09_line197_t.xyz \\
\hline ew09_line198_b.xyz & ew09_line198_t.xyz \\
\hline ew09_line199_b.xyz & ew09_line199_t.xyz \\
\hline ew09_line200_b.xyz & ew09_line200_t.xyz \\
\hline ew09_line201_b.xyz & ew09_line201_t.xyz \\
\hline ew09_line202_b.xyz & ew09_line202_t.xyz \\
\hline ew09_line203_b.xyz & ew09_line203_t.xyz \\
\hline ew09_line204_b.xyz & ew09_line204_t.xyz \\
\hline ew09_line205_b.xyz & ew09_line205_t.xyz \\
\hline ew09_line206_b.xyz & ew09_line206_t.xyz \\
\hline ew09_line207_b.xyz & ew09_line207_t.xyz \\
\hline ew09_line208_b.xyz & ew09_line208_t.xyz \\
\hline ew09_line209_b.xyz & ew09_line209_t.xyz \\
\hline \multicolumn{2}{|l|}{ ew09_line210_b.xyz } \\
\hline ew09_line211_b.xyz & ew09_line211_t.xyz \\
\hline ew09_line212_b.xyz & ew09_line212_t.xyz \\
\hline ew09_line213_b.xyz & ew09_line213_t.xyz \\
\hline ew09_line214_b.xyz & ew09_line214_t.xyz \\
\hline ew09_line215_b.xyz & ew09_line215_t.xyz \\
\hline ew09_line216_b.xyz & ew09_line216_t.xyz \\
\hline ew09_line217_b.xyz & ew09_line217_t.xyz \\
\hline ew09_line218_b.xyz & ew09_line218_t.xyz \\
\hline ew09_line219_b.xyz & ew09_line219_t.xyz \\
\hline ew09_line220_b.xyz & ew09_line220_t.xyz \\
\hline ew09_line221_b.xyz & ew09_line221_t.xyz \\
\hline ew09_line222_b.xyz & ew09_line222_t.xyz \\
\hline ew09_line223_b.xyz & ew09_line223_t.xyz \\
\hline ew09_line224_b.xyz & ew09_line224_t.xyz \\
\hline ew09_line225_b.xyz & ew09_line225_t.xyz \\
\hline ew09_line226_b.xyz & ew09_line226_t.xyz \\
\hline ew09_line227_b.xyz & ew09_line227_t.xyz \\
\hline ew09_line228_b.xyz & ew09_line228_t.xyz \\
\hline ew09_line229_b.xyz & ew09_line229_t.xyz \\
\hline ew09_line230_b.xyz & ew09_line230_t.xyz \\
\hline ew09_line231_b.xyz & ew09_line231_t.xyz \\
\hline ew09_line232_b.xyz & ew09_line232_t.xyz \\
\hline \multicolumn{2}{|l|}{ ew09_line233_b.xyz } \\
\hline \multicolumn{2}{|l|}{ ew09_line234_b.xyz } \\
\hline \multicolumn{2}{|l|}{ ew09_line234_b2.xyz } \\
\hline ew09_001grid_b.xyz & ew09_001grid_t.xyz \\
\hline ew09_002grid_b.xyz & ew09_002grid_t.xyz \\
\hline ew09_003grid_b.xyz & ew09_003grid_t.xyz \\
\hline
\end{tabular}




\begin{tabular}{|l|l|}
\hline ew09_004grid_b.xyz & ew09_004grid_t.xyz \\
\hline ew09_005grid_b.xyz & ew09_005grid_t.xyz \\
\hline ew09_006grid_b.xyz & \\
\hline ew09_007grid_b.xyz & \\
\hline ew09_008grid_b.xyz & \\
\hline ew09_009grid_b.xyz & \\
\hline ew09_010grid_b.xyz & \\
\hline ew09_011grid_b.xyz & \\
\hline ew09_012grid_b.xyz & \\
\hline ew09_013grid_b.xyz & \\
\hline ew09_014grid_b.xyz & \\
\hline ew09_015grid_b.xyz & \\
\hline ew09_016grid_b.xyz & \\
\hline ew09_017grid_b.xyz & \\
\hline ew09_018grid_b.xyz & \\
\hline ew09_019grid_b.xyz & \\
\hline ew09_020grid_b.xyz & \\
\hline ew09_021grid_b.xyz & \\
\hline ew09_022grid_b.xyz & \\
\hline ew09_023grid_b.xyz & \\
\hline ew09_024grid_b.xyz & \\
\hline ew09_025grid_b.xyz & \\
\hline ew09_026grid_b.xyz & \\
\hline ew09_027grid_b.xyz & \\
\hline ew09_028grid_b.xyz & \\
\hline ew09_029grid_b.xyz & \\
\hline ew09_030grid_b.xyz & \\
\hline ew09_031grid_b.xyz & \\
\hline ew09_032grid_b.xyz & \\
\hline ew09_033grid_b.xyz & \\
\hline ew09_034grid_b.xyz & \\
\hline ew09_035grid_b.xyz & \\
\hline ew09_036grid_b.xyz & \\
\hline ew09_037grid_b.xyz & \\
\hline ew09_038grid_b.xyz & \\
\hline ew09_039grid_b.xyz & \\
\hline & \\
\hline & \\
\hline & \\
\hline & \\
\hline & \\
\hline & \\
\hline & \\
\hline & \\
\hline & \\
\hline & \\
\hline
\end{tabular}

